\title{
Nitrogen eutrophication particularly promotes turf algae in coral reefs of the central Red Sea
}

\author{
Denis B Karcher ${ }^{\text {Corresp., } 1}{ }^{1}$, Florian Roth ${ }^{2,3,4}$, Susana Carvalho ${ }^{2}$, Yusuf C El-Khaled ${ }^{1}$, Arjen Tilstra ${ }^{1}$, Benjamin Kürten ${ }^{2}$ \\ ${ }^{5}$, Ulrich Struck ${ }^{6,7}$, Burton H Jones ${ }^{2}$, Christian Wild ${ }^{1}$ \\ 1 Marine Ecology Department, Faculty of Biology and Chemistry, University of Bremen, Bremen, Germany \\ 2 Red Sea Research Center, King Abdullah University of Science and Technology (KAUST), Thuwal, Saudi Arabia \\ 3 Baltic Sea Centre, Stockholm University, Stockholm, Sweden \\ ${ }^{4}$ Tvärminne Zoological Station, Faculty of Biological and Environmental Sciences, University of Helsinki, Helsinki, Finland \\ 5 Project Management Jülich, Jülich Research Centre, Rostock, Germany \\ 6 Museum für Naturkunde, Leibniz Institute for Evolution and Biodiversity Science, Berlin, Germany \\ 7 Department of Earth Sciences, Freie Universität Berlin, Berlin, Germany \\ Corresponding Author: Denis B Karcher \\ Email address: db.karcher@gmx.de
}

While various sources increasingly release nutrients to the Red Sea, knowledge about their effects on benthic coral reef communities is scarce. Here, we provide the first comparative assessment of the response of all major benthic groups (hard and soft corals, turf algae, and reef sands - together accounting for $80 \%$ of the benthic reef community) to in-situ eutrophication in a central Red Sea coral reef. For eight weeks, dissolved inorganic nitrogen (DIN) concentrations were experimentally increased 3-fold above environmental background concentrations around natural benthic reef communities using a slow release fertilizer with $15 \%$ total nitrogen $(\mathrm{N})$ content. We investigated which major functional groups took up the available $\mathrm{N}$, and how this changed organic carbon $\left(\mathrm{C}_{\text {org }}\right)$ and $\mathrm{N}$ contents using elemental and stable isotope measurements. Findings revealed that hard corals (in their tissue), soft corals, and turf algae incorporated fertilizer $\mathrm{N}$ as indicated by significant increases in $\delta^{15} \mathrm{~N}$ by $8 \%, 27 \%$ and $28 \%$, respectively. Among the investigated groups, $\mathrm{C}_{\text {org }}$ content significantly increased in sediments (+24\%) and in turf algae (+33\%). Altogether, this suggests that among the benthic organisms only turf algae were limited by $\mathrm{N}$ availability and thus benefited most from $\mathrm{N}$ addition. Thereby, based on higher $\mathrm{C}_{\text {org }}$ content, turf algae potentially gained competitive advantage over e.g. hard corals. Local management should, thus, particularly address DIN eutrophication by coastal development and consider the role of turf algae as potential bioindicator for eutrophication. 
$1 \quad$ Nitrogen eutrophication particularly promotes turf algae in coral

3

4

6

7 1: Marine Ecology Department, Faculty of Biology and Chemistry, University of Bremen,

8 Bremen, Germany

\section{Tilstra $^{1}$, Benjamin Kürten ${ }^{2,5}$, Ulrich Struck ${ }^{6,7}$, Burton H. Jones ${ }^{2}$, Christian Wild ${ }^{1}$}

2: Red Sea Research Center, King Abdullah University of Science and Technology (KAUST), Thuwal, Saudi Arabia

3: Baltic Sea Centre, Stockholm University, Stockholm, Sweden

4: Tvärminne Zoological Station, Faculty of Biological and Environmental Sciences, University of Helsinki, Helsinki, Finland

5: Project Management Jülich, Jülich Research Centre, Rostock, Germany

6: Museum für Naturkunde, Leibniz Institute for Evolution and Biodiversity Science, Berlin, Germany

7: Department of Earth Sciences, Freie Universität Berlin, Berlin, Germany

\section{*Correspondence}

Corresponding author: Denis B. Karcher

Db.karcher@gmx.de

Marine Ecology Department, Faculty of Biology and Chemistry, University of Bremen

Leobener Str. 6

28359 Bremen, Germany

Keywords: Coral reefs, nutrients, stable isotopes, nitrogen cycling, eutrophication, turf algae, zooxanthellae, phase shifts.

\section{reefs of the central Red Sea}




\section{Abstract}

While various sources increasingly release nutrients to the Red Sea, knowledge about their effects on benthic coral reef communities is scarce. Here, we provide the first comparative assessment of the response of all major benthic groups (hard and soft corals, turf algae, and reef sands - together accounting for $80 \%$ of the benthic reef community) to in-situ eutrophication in a central Red Sea coral reef. For eight weeks, dissolved inorganic nitrogen (DIN) concentrations were experimentally increased 3-fold above environmental background concentrations around natural benthic reef communities using a slow release fertilizer with $15 \%$ total nitrogen $(\mathrm{N})$ content. We investigated which major functional groups took up the available $\mathrm{N}$, and how this changed organic carbon $\left(\mathrm{C}_{\text {org }}\right)$ and $\mathrm{N}$ contents using elemental and stable isotope measurements. Findings revealed that hard corals (in their tissue), soft corals, and turf algae incorporated fertilizer $\mathrm{N}$ as indicated by significant increases in $\delta^{15} \mathrm{~N}$ by $8 \%, 27 \%$ and $28 \%$, respectively. Among the investigated groups, $\mathrm{C}_{\text {org }}$ content significantly increased in sediments $(+24 \%)$ and in turf algae $(+33 \%)$. Altogether, this suggests that among the benthic organisms only turf algae were limited by $\mathrm{N}$ availability and thus benefited most from $\mathrm{N}$ addition. Thereby, based on higher $\mathrm{C}_{\text {org }}$ content, turf algae potentially gained competitive advantage over e.g. hard corals. Local management should, thus, particularly address DIN eutrophication by coastal development and consider the role of turf algae as potential bioindicator for eutrophication.

\section{Introduction}

Coral reefs are among the most productive and biologically diverse ecosystems on the planet (Roberts, 2002), even though they grow in oligotrophic waters of the tropics (Odum \& Odum, 1955). The young and isolated Red Sea, with its thriving coral reefs, is highly oligotrophic, particularly in the subtropical central and northern areas (Raitsos et al., 2013; Sawall et al., 2014b; Kürten et al., 2014; Roth et al., 2018). However, nutrient inputs to the Red Sea from aquaculture (Loya et al., 2004; Kürten et al., 2015; Dunne, 2018; Hozumi et al., 2018) and urban waste water (Basaham et al., 2009; Al-Farawati, 2010; Kürten et al., 2014; Peña-García et al., 2014) affect marine life (Loya et al., 2004; Mohamed \& Mesaad, 2007; Basaham et al., 2009; Naumann et al., 2015). At the same time, the expansion of aquaculture industries in view of the Saudi Arabian coastal development agenda (https://vision2030.gov.sa/en/node), and growing urban sources, e.g. from the city of Jeddah with about 4.6 Mio. inhabitants, (Ministry of Health, 2017), represent further stressors to coral reefs in the Red Sea. Significant parts of the city rely on septic tanks for wastewater which can be a source of nutrients and pollutants through leakages into the groundwater (Abu-Rizaiza \& Sarikaya, 1993; Aljoufie \& Tiwari, 2015). Moreover, the discharge of insufficiently treated sewage from marine outfalls (i.e. pipe discharge) as a pointsource (Risk et al., 2009b; Al-Farawati, 2010) was already shown to raise near-shore $\mathrm{N}$ availability (Sawall et al., 2014b), affect planktonic (Pearman et al., 2018) and coral (Ziegler et 
al., 2016) microbial communities and reach nearby reefs (Risk et al., 2009b; Peña-García et al., 2014). As nutrients, among several stressors, have the largest effect on Red Sea hard coral resilience to climate change (Hall et al., 2018), a deeper understanding of the community response to eutrophication is fundamental.

Benthic coral reef communities are crucial for many ecosystem functions, including the cycling and retention of carbon (C) and nitrogen (N) (Johnson et al., 1995; Wild et al., 2004a; O'Neil \& Capone, 2008) but suffer from anthropogenic disturbances (Hoegh-Guldberg et al., 2007; Carpenter et al., 2008; Hughes et al., 2018). $\mathrm{N}$ availability is an important limiting factor for the biological productivity in oligotrophic reef environments (Lesser et al., 2007). Local eutrophication may impact reef organisms that typically grow in nutrient-poor waters (Naumann et al., 2015), and the diverse array of metabolisms they are comprised of. One prominent example is the entirety of coral host, endosymbiotic algae (zooxanthellae), bacteria and other microorganisms (Wegley et al., 2007), called the coral holobiont. The enrichment source (Shantz \& Burkepile, 2014; Burkepile et al., 2019) and ratio of supplied nutrients is important to determine reef biota's reactions to eutrophication, particularly for corals (Haas, Al-Zibdah \& Wild, 2009; Wiedenmann et al., 2013). Metabolic differences e.g., between autotrophic and heterotrophic lifestyles, as well as the feeding environment of heterotrophic organisms, can lead to imbalances of essential biochemicals, which may become limiting (Müller-Navarra, 2008). Critical parameters to evaluate and trace nutrient fluxes as well as limitations in marine environments are the C and N elemental (Goldman, 1986; Hillebrand \& Sommer, 1999; Sterner \& Elser, 2002; Jessen et al., 2013a; Stuhldreier et al., 2015) and isotopic (Risk et al., 2009a; Baker et al., 2010; Kürten et al., 2014) composition. $N$ uptake and circulation in the reef might be fast, and, while the input of $\mathrm{N}$ can be measured by the long-term increase in forms of $\mathrm{N}$ concentrations (Lapointe et al. 2019), it is most directly traceable in the short-term by the isotopic signature of reef biota. As external sources and processes of $\mathrm{N}$ acquisition affect the isotopic composition, e.g. of corals (Hoegh-Guldberg et al., 2004), anthropogenic N sources can be traced in the field (Costanzo et al., 2001; Kendall, Elliott \& Wankel, 2007; Baker et al., 2010). $\mathrm{N}$ enrichment has negative effects on coral growth (Ferrier-Pagès et al., 2000; Koop et al., 2001; Hall et al., 2018), calcification (Kinsey \& Davies, 1979; Silbiger et al., 2018), reproductive success (Koop et al., 2001; Harrison \& Ward, 2001; Loya et al., 2004), biodiversity (Duprey, Yasuhara \& Baker, 2016), bacterial communities (Hall et al., 2018), and increases the susceptibility of corals to bleaching (Wooldridge \& Done, 2009; Wiedenmann et al., 2013; Vega Thurber et al., 2014; Burkepile et al., 2019). In contrast, other benthic groups in coral reefs, such as turf- and macroalgae benefit from increased nutrient availability in many cases (Lapointe, 1987; Williams \& Carpenter, 1988), particularly in combination with reduced herbivory. Hence, shifts from coral- to algal-dominated reefs, so-called phase shifts, can occur (Lapointe, 1997; Smith, Hunter \& Smith, 2010). 
While extensive research investigated the causes of phase shifts (e.g. McManus \& Polsenberg, 2004; Norström et al., 2009), nutrient effects on the ecophysiology and elemental stoichiometry of reef functional groups are rarely assessed, overlooking connections between uptake to utilization. Responding to the growing nutrient inputs to the central Red Sea, an assessment of their effects on coral reef communities is needed in this originally nutrient poor region, particularly which functional groups and ecophysiological parameters may indicate early-stage effects. Reefs in the oligotrophic Red Sea can serve as a 'natural laboratory' (Berumen et al., 2013, 2019; Pearman et al., 2017), as anthropogenic nutrient inputs add on a comparably low baseline. However, most studies have been conducted in the laboratory rather than in-situ, with associated risks of experimental artifacts, oversimplification or overestimation (Roth et al., 2019). Indeed, local boundary layers and contact zones are of major importance in terms of direct interaction, small scale flow regimes as well as accumulation and transfer of organic matter (Barott \& Rohwer, 2012; Roach et al., 2017), which can hardly be simulated under controlled laboratory conditions. The few similar studies that exist were conducted in less oligotrophic seas (Koop et al., 2001; den Haan et al., 2016), along the natural environmental gradient of the Red Sea (Kürten et al., 2014), focused on one individual benthic group only (Loya et al., 2004; Jessen et al., 2013a,b), or only investigated benthic cover or chlorophyll content, not considering other metabolic parameters (Haas, Al-Zibdah \& Wild, 2009; Naumann et al., 2015).

Therefore, we assessed the responses of major benthic functional groups (hard corals [Pocillopora cf. verrucosa, i.e. tissue and zooxanthellae], soft corals [Xeniidae], turf algae, and sediments) to $\mathrm{N}$ enrichment through a manipulative in-situ experiment in the central Red Sea. Combining elemental and stable isotope analysis, this approach provides information starting from $\mathrm{N}$ in the water column, through $\mathrm{N}$ uptake, to its utilization. We address the following underlying research questions: 1) Which major functional groups take up available $\mathrm{N}$ and 2) how did this affect organic carbon $\left(\mathrm{C}_{\text {org }}\right)$ and $\mathrm{N}$ contents? Taken together, we aimed to draw conclusions about nutrient limitation for different functional groups.

\section{Materials \& Methods}

\section{Study site and environmental conditions}

The experiments were conducted at Abu Shoosha reef $\left(22^{\circ} 18^{\prime} 15^{\prime \prime} \mathrm{N}, 39^{\circ} 02^{\prime} 56^{\prime \prime}\right.$ E) on the west coast of Saudi Arabia in the central Red Sea from late January until late March 2018. The reef assessed in this study does not fall under any legislative protection or special designation as a protected area. Under the auspices of KAUST (King Abdullah University of Science and Technology), sailing permits to the reef were granted that included the collection of corals and other reef benthos. This reef is characterized by generally high levels of herbivory and small 
141 fluctuations in ambient DIN concentration during this period (Roth et al., 2018). For example, in 142 January to March of the previous year (i.e., 2017), sea water concentrations of ammonium $143\left(\mathrm{NH}_{4}^{+}\right)$ranged from 0.16 to $0.17 \mu \mathrm{M}$, nitrate $\left(\mathrm{NO}_{3}{ }^{-}\right)$from 0.25 to $0.40 \mu \mathrm{M}$, nitrite $\left(\mathrm{NO}_{2}{ }^{-}\right)$from 1440.03 to $0.06 \mu \mathrm{M}$, phosphate $\left(\mathrm{PO}_{4}{ }^{3-}\right)$ from 0.02 to $0.21 \mu \mathrm{M}$, and the resulting $\mathrm{DIN}\left(\mathrm{NO}_{3}{ }^{-}+\mathrm{NO}_{2}+\right.$ $145 \mathrm{NH}_{4}{ }^{+}$)/ $\mathrm{PO}_{4}{ }^{3-}$ ratio from 2.9:1 to 20:1 (Roth et al., 2018, Table S4). Abu Shoosha reef features

146 147 turf algae $(37 \%)$ and hard corals $(29 \%)$ as most abundant functional groups (Table 1$)$.

Key environmental variables were monitored every two to three weeks at the sampling site, as described in a related study by Roth et al. (2018). Briefly, water temperature was measured with continuous data loggers (Onset HOBO Water Temperature Pro v2 Data Logger - U22-001; accuracy: $\pm 0.21^{\circ} \mathrm{C}$ ) and are given in 3-day means $(72 \mathrm{~h})$. For background measurements of dissolved $\mathrm{NO}_{3}{ }^{-}, \mathrm{NO}_{2}{ }^{-}$and $\mathrm{PO}_{4}{ }^{3-}$, water samples were taken in triplicates at the study site at least $2 \mathrm{~m}$ away from any fertilizer source (see 'Experimental design and sampling strategy' for more details). Water samples were filtered on the boat (Isopore ${ }^{\mathrm{TM}}$ membrane filters, $0.2 \mu \mathrm{m}$ GTTP) and stored dark and cool until they were frozen to $-50{ }^{\circ} \mathrm{C}$ in the lab. Nutrient concentrations were determined with a continuous flow analyzer (AA3 HR, SEAL). The limits of quantification (LOQ) for $\mathrm{NO}_{3}{ }^{-}, \mathrm{NO}_{2}{ }^{-}$and $\mathrm{PO}_{4}{ }^{3-}$ were $0.084 \mu \mathrm{mol} \mathrm{L}{ }^{-1}, 0.011 \mu \mathrm{mol} \mathrm{L} \mathrm{L}^{-1}$, and $0.043 \mu \mathrm{mol} \mathrm{L}{ }^{-1}$ respectively. $5 \mathrm{~mL}$ subsamples for $\mathrm{NH}_{4}^{+}$were filtered into separate acid washed centrifuge tubes. $1.2 \mathrm{~mL}$ ortho-phthalaldidehydesolution (OPA) was added, and samples were incubated $>4 \mathrm{~h}$ with OPA in the dark. $\mathrm{NH}_{4}{ }^{+}$concentrations were determined fluorometrically within $8 \mathrm{~h}$ (Trilogy® Laboratory Fluorometer, Turner Designs Inc.). The LOQ for $\mathrm{NH}_{4}{ }^{+}$was $0.094 \mu \mathrm{mol} \mathrm{L}{ }^{-1}$. The sum of $\mathrm{NO}_{3}{ }^{-}, \mathrm{NO}_{2}{ }^{-}$and $\mathrm{NH}_{4}{ }^{+}$concentrations reflect DIN.

\section{Experimental design and sampling strategy}

Eight distinct patches of reef communities, each surrounded by patches of reef sand, were chosen in the back reef of $\mathrm{Abu}$ Shoosha at a water depth of approximately $5 \mathrm{~m}$. The chosen communities, which represented the surrounding reef in composition (Table 1), were exposed to simulated eutrophication for eight weeks in total. More specifically, each of the replicate communities was surrounded by four pins with approximately $70 \mathrm{~g}$ of slow release fertilizer granulate (Osmocote ${ }^{\circledR}$ Plus (15-9-12)) (Fig. 1). Being one of the most commonly used fertilizers for eutrophication experiments (Wheeler, 2003; Russell et al., 2009; Falkenberg, Russell \& Connell, 2013; Stuhldreier et al., 2015), this approach provides a fast and high supply of macronutrients $(15 \%$ total $\mathrm{N}$ [ $8 \%$ nitrate N, $7 \%$ ammoniacal $\mathrm{N}], 9 \%$ available phosphate, $12 \%$ soluble potash) from the first day of fertilization under local temperature regimes (Adams, Frantz \& Bugbee, 2013). Osmocote $\AA$ Plus (15-9-12) provides a balanced fertilization of $N$ and phosphorus (P), however, only the fate of $\mathrm{N}$ was considered in this experiment as particularly $\mathrm{N}$ effects were of interest. The fertilizer was renewed every two to three weeks to assure a continuous nutrient supply (Adams, Frantz \& Bugbee, 2013). To test whether the nutrient addition was effective locally, water samples for nutrients were taken directly at the fertilizer pin, and $25 \mathrm{~cm}$ towards the manipulated communities according to the protocol outlined above. 
180

181

182

183

184

185

186

187

188

189

190

191

192

193

194

195

196

197

198

199

200

201

202

203

204

205

206

207

208

209

210

211

212

213

214

215

216

217

218

The effect of eutrophication was then assessed at the major functional groups (in terms of benthic reef cover in the central Red Sea) that were present in the selected communities. Specifically, we chose autotrophic hard corals (Pocillopora cf. verrucosa), soft corals (Xeniidae), turf algae and reef sand (sediments). These groups covered $\sim 80 \%$ of the sampled reef (Roth et al., 2018). Turf algae were defined as dense and flat (less than $2 \mathrm{~cm}$ in height) assemblages of filamentous algae of different species, including small individuals of macroalgae and cyanobacteria.

Manipulated specimens ('treatment') were sampled from within a close radius $(\sim 25 \mathrm{~cm})$ of the fertilizer tubes. As the in-situ communities were also needed in other experiments investigating their $\mathrm{C}$ chemistry (F Roth et al., unpublished) and $\mathrm{N}$ fluxes (Y El-Khaled et al., in review), specimens for natural conditions at the beginning ('start') of the experiment were collected in the surrounding reef. Additional samples in replicates of eight were collected in the surrounding non-fertilized reef at the end ('control') of the experiment, to reflect non-fertilized control conditions. For start and control data, a distance of at least $10 \mathrm{~m}$ from any fertilizer pin was maintained and the same depth as well as light conditions were given.

Samples were acquired with hammer and chisel. Hard coral and turf fragments (their substrate) were of approx. $10 \mathrm{~cm}$ in length. Sediments were collected using a Petri dish, which was dragged into the sediment upside-down (max. depth $14 \mathrm{~mm}$ ) and the sediment was fixed to the dish from underneath. The samples were stored at $-80^{\circ} \mathrm{C}$ until further preparation. Hard corals, soft corals and turf algae were rinsed with Milli-Q to remove excess salt. Epilithic turf algae were scraped off from their surface with a scalpel and tweezers.

\section{Elemental and stable isotopic compositions of $C$ and $N$}

Turf algae, soft corals and sediments were dried for $48 \mathrm{~h}$ (sediments: $72 \mathrm{~h}$ ) at $40{ }^{\circ} \mathrm{C}$. Following Jessen et al. (2013b), hard coral tissue was removed using an airbrush, and the resulting tissue slurry was weighed, homogenized (MicroDisTec 125) and centrifuged for $10 \mathrm{~min}$ (Eppendorf Centrifuge $5430 \mathrm{R}, 4{ }^{\circ} \mathrm{C}, 3220 \mathrm{rcf}$ ) to separate algae ('zooxanthellae') from animal 'tissue'. The supernatant was filtered (Whatman, GF/F) and for each sample two filters were generated. Filters for $\mathrm{N}$ and inorganic $\mathrm{C}$ analysis were dried for $24 \mathrm{~h}$ at $40{ }^{\circ} \mathrm{C}$. Filters for $\mathrm{C}_{\text {org }}$ measurements were exposed to $\mathrm{HCl}$ fumes (from $37 \% \mathrm{HCl}$ ) and dried for $24 \mathrm{~h}$. The remaining zooxanthellae pellet was dried for $48 \mathrm{~h}$ at $40{ }^{\circ} \mathrm{C}$.

Sub-samples of all groups were ground using an agate mortar and pestle. A mill grinder (Retsch, PM 200, 4 min) was used for the sediments. For preparation of $\mathrm{C}_{\text {org }}$ samples, 5-10 $\mathrm{g}$ of ground sediment were placed in an Erlenmeyer flask and covered with Milli-Q. Drops of $\mathrm{HCl}$ (37 \%) were added until the reaction ceased. The acidified liquid was transferred to $50 \mathrm{~mL}$ Falcon tubes which were filled up with Milli-Q, to stepwise wash the sample pellet and raise the $\mathrm{pH}$ up to neutrality, and subsequently centrifuged for $10 \mathrm{~min}$ (Eppendorf Centrifuge $5430 \mathrm{R}, 4{ }^{\circ} \mathrm{C}, 7200$

Peer] reviewing PDF | (2019:11:42898:1:2:NEW 9 Feb 2020) 
219

220

221

222

223

224

225

226

227

228

229

230

231

232

233

234

235

236

237

238

239

240

241

242

243

244

245

246

247

248

249

250

251

252

253

254

255

rcf). The liquid supernatant was discarded and tubes were then refilled with Milli-Q for 3 to 4 times to raise $\mathrm{pH}$. The pellets were dried in the Falcon tubes for $48 \mathrm{~h}$ at $40{ }^{\circ} \mathrm{C}$.

The dry, homogenous powder was analyzed for: a) $\mathrm{N}$ and inorganic $\mathrm{C}$ quantities; and b) $\mathrm{C}_{\text {org }}$ as in Roth et al. (2018). $\mathrm{C}_{\text {org }} / \mathrm{N}$ ratios, fractions of organic and inorganic $\mathrm{C}$ and isotope ratios were measured as in Rix et al. (2018) using a Flash 1112 EA coupled to a Delta V IRMS via a ConfloIV- interface (Thermo Scientific). Isotopic ratios are shown as $\delta^{13} \mathrm{C}$ or $\delta^{15} \mathrm{~N}(\%)=\left(R_{\text {sample }}\right.$ $\left./ R_{\text {ref }}-1\right) \times 1000$. There, $R$ is the ratio of heavier:lighter isotope $\left({ }^{13} \mathrm{C}:{ }^{12} \mathrm{C}\right.$ or $\left.{ }^{15} \mathrm{~N}:{ }^{14} \mathrm{~N}\right)$. As reference, Vienna Pee Dee Belemnite was used for $C\left(\mathrm{R}_{\text {ref }}=0.01118\right)$ and atmospheric nitrogen for $\mathrm{N}\left(\mathrm{R}_{\mathrm{ref}}=0.00368\right)$.

\section{Zooxanthellae cell density and mitotic index}

For hard corals, zooxanthellae cell density and the mitotic index were analyzed following the described sampling strategy (start, control, treatment), whereby 'start' and 'control' were from the surrounding reef. Aliquots of $20 \mu \mathrm{L}$ homogenized tissue sample and $80 \mu \mathrm{L}$ Milli-Q were vortexed (Gilson, GVLab) directly before taking $10 \mu \mathrm{L}$ on an improved Neubauer Levy hemocytometer $(0.0100 \mathrm{~mm}$ deep). Pictures were taken with a ZEISS Primovert microscope via Labscope (Version 2.5) from the $5 \times 5$ grid in 40-fold and randomly in 20-fold magnification. Manual counts of zooxanthellae and the mitotic index were related to the total amount of airbrushed slurry per individual. Here, clumps and inhomogeneous patches were not considered. For normalization to the coral surface area, 3D models for all coral skeletons were generated using the software AutodeskReCap Photo (v18.2.0.8).

\section{Data analysis}

$\mathrm{N}$ uptake by functional groups was assessed using stable isotope analysis. $\mathrm{N}$ utilization was assessed by elemental analysis, and $\mathrm{C}_{\mathrm{org}} \mathrm{N}$ ratios served to identify nutrient limitations (Lapointe, Littler \& Littler, 1992; Hillebrand \& Sommer, 1999; Sterner \& Elser, 2002; Lapointe et al., 2005), along with zooxanthellae cell density and mitotic index (for hard corals). Statistical analysis was conducted with RStudio (R Core Team, 2017). Xeniidae and Pocillopora cf. verrucosa were not abundant in all 8 communities (only in 5 and 6 , respectively). Due to logistical constraints, 'start' data of soft corals was not available. A two-way ANOVA (factors: treatment, dominant functional group) showed no significant effect of community composition on our response parameters under $\mathrm{N}$ eutrophication, therefore data from more coral and more algae dominated communities were pooled. Significant differences between 'start' and 'control' as well as between 'control' and 'treatment' were checked with two-sample t-tests (test statistic: t) if test assumptions were fulfilled, otherwise Mann-Whitney-Wilcoxon Tests (test statistic: W) were applied. A similar approach was conducted for cell density of zooxanthellae and mitotic index per treatment. Tissue homogenization of the 'start' samples was visually much worse than for 'treatment' and 'control' samples, but is shown for completeness and homogeneity. 
257

258

259

260

261

262

263

264

265

266

267

268

269

270

271

272

273

274

275

276

277

278

279

280

281

282

283

284

285

286

287

288

289

\section{Results}

\section{Environmental parameters and $N$ availability}

During the study period, water temperature increased from 25 to $28{ }^{\circ} \mathrm{C}$ (Table $\mathrm{S} 1$ ). The mean background concentration in sea water for DIN was $0.34 \pm 0.07 \mu \mathrm{M} \mathrm{N}$ and $0.10 \pm 0.02 \mu \mathrm{M} \mathrm{PO}_{4}{ }^{3-}$ during the time of the experiment (measured after 2, 4 and 6.5 weeks). Accordingly, the environmental background $\mathrm{DIN} / \mathrm{PO}_{4}{ }^{3-}$ ratio was $3.4( \pm 0.08): 1$ on average. The manipulation of nutrients increased DIN concentrations (measured after 2, 4 and 6.5 weeks) on average 3-fold and to a maximum of 7-fold directly at the communities relative to background concentrations (Fig. 2). Namely, manipulated $\mathrm{NO}_{3}{ }^{-}$was $1.05 \pm 0.09 \mu \mathrm{M}$ and manipulated $\mathrm{NH}_{4}{ }^{+}$was $0.22 \pm 0.06$ $\mu \mathrm{M} . \mathrm{PO}_{4}{ }^{3-}$ remained at ambient condition, despite being present in the fertilizer (Table S1). As such, the mean DIN/PO ${ }_{4}^{3-}$ ratio at the manipulated communities was $15.1( \pm 3.46): 1$.

\section{Uptake of excess $N$ by benthic functional groups}

Pure Osmocote ${ }^{\circledR}$ fertilizer was enriched in ${ }^{15} \mathrm{~N}\left(\delta^{15} \mathrm{~N}=16.326 \pm 0.257\right.$, Table S2). Hard corals (tissue), turf algae, and soft corals took up excess $\mathrm{N}$, as indicated by significantly $\left(\mathrm{t}_{12}=2.553, \mathrm{p}\right.$ $=0.025 ; \mathrm{t}_{13}=3.228, \mathrm{p}=0.007 ; \mathrm{t}_{9}=6.705, \mathrm{p}<0.001$, respectively) increased $\delta^{15} \mathrm{~N}$ (Fig. 3A). The $\delta^{15} \mathrm{~N}$ values in manipulated functional groups were $8 \%$ (Pocillopora tissue), $27 \%$ (Xeniidae), and $28 \%$ (turf algae) higher compared to untreated controls after the same time.

\section{Utilization of excess $N$ by benthic functional groups}

$\mathrm{N}$ content was highest in hard coral zooxanthellae both before and after eutrophication (Fig. 3B). In the eutrophication treatment, $\mathrm{N}$ content was significantly higher in the tissues of Xeniidae $\left(\mathrm{t}_{9}=\right.$ 5.667, $\mathrm{p}<0.001)$, and turf algae $(\mathrm{W}=49, \mathrm{p}=0.014)$. Their tissues contained $85 \%$ (Xeniidae) and $39 \%$ (turf) more $\mathrm{N}$ compared to untreated controls. Increases in the other groups were not significant.

To investigate whether $\mathrm{N}$ was utilized to produce $\mathrm{C}_{\text {org }}$ under a metabolically stable ratio, the $\mathrm{C}_{\text {org }}$ content and $\mathrm{C}_{\text {org }} / \mathrm{N}$ ratio are presented. The hard coral components showed the highest $\mathrm{C}_{\text {org }}$ content ranging from $50.39 \pm 1.83 \%$ to $55.05 \pm 1.49 \%$ in the tissue and between $42.64 \pm 1.39 \%$ to $45.78 \pm 1.49 \%$ in zooxanthellae (Fig. 3C). Minimum $\mathrm{C}_{\text {org }}$ content was observed in reef sediments, ranging between $0.09 \pm 0.01 \%$ and $0.11 \pm 0.01 \%$. Only turf algae and sediments showed a significant change in $\mathrm{C}_{\text {org }}$ content $\left(\mathrm{t}_{14}=2.568, \mathrm{p}=0.022 ; \mathrm{t}_{14}=2.537, \mathrm{p}=0.023\right.$, respectively). This represents an increase in $\mathrm{C}_{\text {org }}$ content by $33 \%$ in turf algae and $24 \%$ in sediments in the treatment compared control specimen. 
290 The $\mathrm{C}_{\text {org }} / \mathrm{N}$ ratio for treated Xeniidae was significantly lower $\left(\mathrm{t}_{8}=-6.405, \mathrm{p}<0.001\right)$ than for 291 Xeniidae in the surrounding reef $(8.520 \pm 0.320$ compared to $4.132 \pm 0.566$, Fig. 3D). In 292 sediments of the eutrophication 'treatment' the $\mathrm{C}_{\text {org }} / \mathrm{N}$ ratio was significantly higher than in 293 controls $(\mathrm{W}=53, \mathrm{p}=0.028)$, however it did not increase compared to start values. In hard coral 294 zooxanthellae, $\mathrm{C}_{\text {org }} / \mathrm{N}$ ratio declined over time but was not significantly different in treatment

295 296

297

298

299

300

301

302

303

304

305

306

307

308

309

310

311

312

313

314

315

316

317

318

319

320

321

322

323

324

325 data compared to controls. $\mathrm{C}_{\text {org }} / \mathrm{N}$ remained constant in hard coral tissue and turf algae.

Cell density of hard coral zooxanthellae (Pocillopora cf. verrucosa) doubled over the eight weeks, while their mitotic index halved (Fig. 4A and B). However, zooxanthellae density and mitotic index in fertilized and control corals remained similar. After eight weeks, cell densities ranged from $1.324 \pm 0.147 \mathrm{Mio}$. cells cm $\mathrm{cm}^{-2}$ (treatment) to $1.373 \pm 0.172 \mathrm{Mio}$. cells cm $\mathrm{cm}^{-2}$ (control), whereas the mitotic index ranged from $4.718 \pm 0.445 \%$ and $4.901 \pm 0.244 \%$ in organisms under control and $\mathrm{N}$ enrichment conditions, respectively.

\section{Discussion}

Studies on the effects of eutrophication in the oligotrophic central Red Sea are scarce, and have, so far, focused on eutrophication effects on single functional groups only, used natural gradients or left out impacts on the elemental stoichiometry. In a comparative in-situ approach we therefore provide an assessment of eutrophication effects on several major functional groups' ecophysiology using elemental and stable isotope analysis, drawing conclusions on $\mathrm{N}$ uptake and utilization.

\section{Uptake of excess $N$ by major benthic functional groups}

In-situ $\mathrm{N}$ enrichment resulted in an uptake of $\mathrm{N}$ in the tissues of turf algae, soft corals and hard corals, but not in sediments and hard coral zooxanthellae. The fact that turf algae exhibited the lowest $\delta^{15} \mathrm{~N}$ at the start of our experiment suggests considerable assimilation of $\mathrm{N}$ from $\mathrm{N}_{2}$ fixation (Yamamuro, Kayanne \& Minagawao, 1995; Rix et al., 2015; Tilstra et al., 2017; Y ElKhaled et al., in review). Biological fixation of atmospheric $\mathrm{N}_{2}$ leads to a depletion in ${ }^{15} \mathrm{~N}$ in the $\mathrm{N}$ compounds of the fixer (Carpenter et al., 1997; Karl et al., 2002). After the experiment, turf algae showed one of the strongest uptakes of $\mathrm{N}$ from the fertilizer among the benthic reef functional groups, as indicated by significantly higher $\delta^{15} \mathrm{~N}$ values (Fig. 3A), which concurs with den Haan et al. (2016). The low DIN/PO ${ }_{4}^{3-}$ ratio in ambient waters at the reef further suggests a relatively low degree of P-limitation under ambient conditions, which may help to explain the strong uptake of $\mathrm{N}$ when available. Concordantly, Lapointe et al. (2019) showed that in the eutrophic waters of the Florida Keys, the N:P ratio of turf algae (293:1) increased to a much greater extent than that of macroalgae (71:1) as DIN concentrations increased over a 3-decade period. Also soft corals incorporated fertilizer $\mathrm{N}$ and reached higher $\delta^{15} \mathrm{~N}$ values than typical for 
326

327

328

329

330

331

332

333

334

335

336

337

338

339

340

341

342

343

344

345

346

347

348

349

350

351

352

353

354

355

356

357

358

359

360

361

362

363

364

soft corals that are exposed to industrial and urban run-off in the central Red Sea (Kürten et al., 2014).

In the present experiment, the uptake of excess $\mathrm{N}$ was not noticeable in the sediment $\delta^{15} \mathrm{~N}$, in contrast to a study by Miyajima et al. (2001). There, sediment microflora took up $\mathrm{NO}_{3}{ }^{-}$and $\mathrm{NH}_{4}{ }^{+}$ in bottle incubations (Miyajima et al., 2001), and assimilation as well as adsorption of $\mathrm{N}$ compounds on carbonate reef sands were observed (Erler, Santos \& Eyre, 2014). This would suggest fast nutrient uptake, especially in microalgae on the sediments, and high uptakes into pore water, as reported by Rasheed, Badran \& Huettel (2003) and Erler, Santos \& Eyre (2014). Pore water was not targeted in our study and a change of isotopic signature in the sediment could take longer than the current experimental period, as previously suggested by Cook et al. (2007) who did not find clear $\delta^{15} \mathrm{~N}$ patterns in $\mathrm{N}$ manipulated sediments. This would account for the integration time of isotopic signatures through the food-web (Rolff, 2000; O'Reilly et al., 2002). In agreement to our study, Koop et al. (2001) also did not find high $\delta^{15} \mathrm{~N}$ uptake in sediments. Potentially, organisms on and in the sediments are not N-limited, given that sediments are active sites of microbial $\mathrm{N}$ transformations (Capone et al., 1992) and remineralization (Tribble, Sansone \& Smith, 1990) allowing for $\mathrm{N}$ recycling.

Within the hard coral holobiont, the zooxanthellae did not incorporate excess $\mathrm{N}$ significantly. This generally agrees with Koop et al. (2001) and den Haan et al. (2016) showing that hard corals (i.e., Madracis mirabilis) take up less excess nutrients than turf or macroalgae. Most studies, however, report stronger $\delta^{15} \mathrm{~N}$ enrichment in the zooxanthellae fraction compared to host tissue (Grover et al., 2002; Pernice et al., 2012; Kopp et al., 2013). There are several possibilities why this was not observed in our study. Firstly, $\mathrm{NO}_{3}^{-}$uptake in zooxanthellae can be highest under low $\mathrm{NH}_{4}{ }^{+}$availability (Grover et al., 2003; Tanaka et al., 2017), however, $\mathrm{NH}_{4}^{+}$was elevated $\sim 5$-fold compared to the environmental background in our experiment (Table S1). Secondly, P can be a limiting factor to zooxanthellae's N uptake (Godinot et al., 2011). Unlike the highly increased $\mathrm{N}$ availability, the $\mathrm{P}$ provided by our fertilizer did not alter the $\mathrm{PO}_{4}{ }^{3-}$ concentration $25 \mathrm{~cm}$ away from the source (Table S1). The resulting increased DIN/ $\mathrm{PO}_{4}{ }^{3-}$ ratio at the communities underlines a stronger P-limitation under manipulation. Potentially, reef sediments (Millero et al., 2001) or organisms in the water column and the surrounding benthos took up $\mathrm{PO}_{4}{ }^{3-}$ too quickly as $\mathrm{P}$ was stated crucial (Cuet et al., 2011) and limiting (Lapointe, Littler \& Littler, 1992; Eyre, Glud \& Patten, 2008; Kürten et al., 2014) for primary production in coral reefs. However, we acknowledge dissimilar findings on the limiting roles of $\mathrm{N}$ and $\mathrm{P}$ in the central Red Sea (Peña-García et al., 2014). The understanding of P cycling and limitation in coral reef environments is still in its infancy (Ferrier-Pagès et al., 2016), but $\mathrm{PO}_{4}{ }^{3-}$ could have been limiting for significant $\mathrm{N}$ uptake in zooxanthellae (Godinot et al., 2011). In contrast to other findings (Grover et al., 2003; Tanaka et al., 2006), coral tissue incorporated more available $\mathrm{N}$ than the symbionts. This suggests that the host tissue was less P-limited than the zooxanthellate fraction, and hence took up relatively more N. This is corroborated by the low DIN/PO ${ }^{3-}$ ratio of 
3653.4 in ambient waters of the studied reef that indicates N- rather than P-limitation, confirming 366 Al-Farawati et al. (2018).

367

368

369

370

371

372

373

374

375

376

377

378

379

380

381

382

383

384

385

386

387

388

389

390

391

392

393

394

395

396

397

398

399

400

401

402

403

\section{Utilization of excess $N$ by benthic functional groups}

Due to eutrophication, tissue $\mathrm{N}$ content significantly increased in turf algae and soft corals but not in hard corals and sediments. $\mathrm{C}_{\text {org }}$ content remained constant in hard and soft corals but increased in sediments and turf algae. Thus, turf algae and hard coral tissue remained at constant $\mathrm{C}_{\text {org }} / \mathrm{N}$ ratio, while it decreased in soft corals and showed unclear trends in hard coral zooxanthellae and sediments.

For turf algae, $\mathrm{N}$ and $\mathrm{C}_{\text {org }}$ content were significantly higher under nutrient addition compared to controls, which contrasts findings by Stuhldreier et al. (2015) reporting no such eutrophication effects on turf algae dominated settlement communities. In the present study, relatively similar increases in $\mathrm{N}$ content $(+39 \%)$ and $\mathrm{C}_{\text {org }}$ content $(+33 \%)$ occurred and the $\mathrm{C}_{\text {org }} / \mathrm{N}$ ratio stayed constant (between 9.1 and 9.3). Hence we interpret $\mathrm{N}$ to be a limiting nutrient (Hecky, Campbell \& Hendzel, 1993) for turf algae growth, which also corroborates other studies (Hatcher \& Larkum, 1983; Williams \& Carpenter, 1988; McCook, 1999). Turf algae are strong opponents to corals (Airoldi, 1998; Roth et al., 2018), and their competitiveness under high-nutrient availability has been documented in Hawaii (Smith, Smith \& Hunter, 2001), the Caribbean (Vermeij et al., 2010), Brazil (Costa et al., 2000), Australia (Gorgula \& Connell, 2004) and in the Red Sea (Naumann et al., 2015). As turf algae are also rapidly taking over bare substrates (Stuhldreier et al., 2015; Roth et al., 2018) and are very resistant to disturbances (Airoldi, 1998), their monitoring should be on regional management agendas. Cover data was not documented in the present study but turf algae growth could be speculated upon based on increases in $\mathrm{C}_{\text {org }}$ content.

$\mathrm{N}$ was taken up by soft corals while the $\mathrm{C}_{\text {org }}$ content did not increase, resulting in an altered elemental stoichiometry $\left(\mathrm{C}_{\text {org }} / \mathrm{N}\right.$ ratio). The strong decline in the soft corals' $\mathrm{C}_{\text {org }} / \mathrm{N}$ ratio could be explained by an uptake of excess $\mathrm{N}$ as so-called 'luxury consumption' (Sterner \& Elser, 2002; p. 82), describing on-going uptake while a different nutrient (e.g. P) might limit growth and productivity. We interpret that in our eutrophication experiment $\mathrm{P}$ rather than $\mathrm{N}$ was the limiting nutrient for soft corals, which may limit chlorophyll $a$ content and photosynthesis in Xeniidae (Bednarz et al., 2012). Our data from elemental analysis and non-documented visual observations support the hypothesis of Fabricius et al. (2005) that soft corals could react more timely and strongly to water quality gradients than hard corals.

Our results further correspond to other studies (Capone et al., 1992; Rasheed, Badran \& Huettel, 2003; Wild et al., 2004b) finding low $\mathrm{C}_{\text {org }}$ content in carbonate dominated reef sands $(0.18-0.36$ $\%)$, which were even lower in our study $(0.1 \%)$. We acknowledge that the utilized acid wash-out processing may underestimate $\mathrm{C}_{\text {org }}$ contents due to $\mathrm{C}_{\text {org }}$ losses to the liquid acid of 4 to $52 \%$ (Yamamoto, Kayanne \& Yamamuro, 2001) and as such lower the $\mathrm{C}_{\text {org }} / \mathrm{N}$ ratio. However, this is a commonly used method in comparative studies (Rasheed, Badran \& Huettel, 2003; Wild et al., 2004b). The observed $21 \%$ increase in $\mathrm{C}_{\text {org }}$ could be attributed to P-supported algae growth on 
404 the sediments (Fig. S1) as fertilizer $\mathrm{N}$ was not taken up (constant $\delta^{15} \mathrm{~N}$ ) but gross primary

405

406

407

408

409

410

411

412

413

414

415

416

417

418

419

420

421

422

423

424

425

426

427

428

429

430

431

432

433

434

435

436

437

438

439

440

441

442

443 production significantly increased ( $\mathrm{Y}$ El-Khaled et al., in review). A different source for the increased $\mathrm{C}_{\text {org }}$ content in sediments could be the export of $\mathrm{C}_{\text {org }}$ from turf algae ( $\mathrm{F}$ Roth et al., in review) e.g. as dissolved organic carbon (DOC) (Haas et al., 2011) and subsequent uptake by reef sediments, as suggested by Cárdenas et al. (2015). This, along with the low $\mathrm{C}_{\text {org }} / \mathrm{N}$ ratio, corroborates the previous assumption that life in and on the sediments, as well as its increase in $\mathrm{C}_{\text {org }}$ content was not $\mathrm{N}$ limited.

Regarding the hard coral holobiont, our results suggest that the incorporation of excess $\mathrm{N}$ only to the host tissue did not result in its utilization in terms of $\mathrm{C}_{\text {org }}$ production. As such, $\mathrm{C}_{\text {org }} / \mathrm{N}$ ratios for Pocillopora cf. verrucosa contrast a study conducted in $10 \mathrm{~km}$ distance to our study site further offshore at the same time of the year in 2012 (Ziegler et al., 2014). There, the natural host total $\mathrm{C}: \mathrm{N}$ ratio was around 5 , which makes our presented host material appear more $\mathrm{N}$ depleted in comparison. Over time, we observed an increase in symbiont cell density, which contrasts with other studies finding higher zooxanthellae cell densities in Pocillopora species in cooler and more nutrient rich phases (Stimson, 1997; Al-Sofyani \& Floos, 2013; Sawall et al., 2014a). However, particularly the similarity between treatment and non-fertilized controls should be considered where cell density and mitotic index did not differ. Similar findings have been reported by Ferrier-Pagès et al. (2001) and Rosset et al. (2017) during pure N fertilization but contrast with other studies (Stambler et al., 1991; Muller-Parker, Cook \& D'Elia, 1994; Fabricius, 2005) finding increased zooxanthellae cell density in hard corals i.e. after only 18 days of eutrophication (Falkowski et al., 1993) or following a natural nutrient gradient (Sawall et al., 2011). Altogether, this suggests that $\mathrm{N}$ was not a limiting factor for zooxanthellae in our experiment. The production (Ezzat et al., 2016), health, and density (Tanaka et al., 2017) of zooxanthellae cells was found to be $\mathrm{P}$ limited. Accordingly, high $\mathrm{P}$ availability resulted in higher increases of zooxanthellae density (Pocillopora damicornis and Euphyllia paradivisa) than availability of only N (Stambler et al., 1991; Rosset et al., 2017). As a consequence, we hypothesize that hard corals also did not shift in primary productivity, even though a significant increase in $\delta^{13} \mathrm{C}$ in hard coral zooxanthellae (Fig. S2) could be a sign of increased photosynthesis (Swart, Saied \& Lamb, 2005) e.g. following a seasonal pattern (F Roth et al., in review). However, gross primary production did not increase in our manipulated hard corals (Y El-Khaled et al., in review). The increased $\delta^{13} \mathrm{C}$ in the zooxanthellae (Fig. S2) could also be an indicator for a negative effect on hard coral health which was also found in relation to bleached Favia favus corals in the Northern Red Sea (Grottoli, Tchernov \& Winters, 2017) but not Montastraea faveolata in Florida (Wall et al., 2019). Given our eight-week observation period and a comparatively cold water temperature, our study did not provide a setting to trace severe bleaching effects and for the Southern Red Sea it was speculated that higher nutrient availability might even benefit $P$. verrucosa to resist higher water temperature (Sawall et al., 2014a). This corroborates that effects of eutrophication on coral health are not always negative (Bongiorni et al., 2003; Sawall et al., 2011; Ezzat et al., 2019) and do not necessarily harm or kill individual 
444

445

446

447

448

449

450

451

452

453

454

455

456

457

458

459

460

461

462

463

464

465

466

467

468

469

470

471

472

473

474

475

476

477

478

479

480

481

coral colonies but get outcompeted or overgrown over time (reviewed in Fabricius, 2005). Longer (3 years; Vega Thurber et al., 2014), and both longer and stronger (1 year, $36.2 \mu \mathrm{M}$ $\mathrm{NH}_{4}^{+}$; Koop et al., 2001) $\mathrm{N}$ manipulation could, however, lead to increased coral mortality (Koop et al., 2001). In particular, reviewed findings (Morris et al., 2019), natural long-term observations (Lapointe et al., 2019) and laboratory experiments (Wiedenmann et al., 2013; Rosset et al., 2017) with high $\mathrm{N}(>3 \mu \mathrm{M}$ and $38 \mu \mathrm{M}$ N, respectively) and low P supply $(<0.07 \mu \mathrm{M}$ and $0.18 \mu \mathrm{M} \mathrm{P}$, respectively) increased susceptibility of corals to bleaching, which suggests negative effects. In agreement with Ezzat et al. (2016) and Ferrier-Pagès et al. (2016), we suggest increasing efforts investigating $\mathrm{P}$ cycling and limitation in current and future reef ecosystems. Besides this key role of nutrient ratios, Burkepile et al. (2019) highlight the importance to also account for varying effects of different forms of $\mathrm{N}$. As $\mathrm{N}$ sources and pathways in corals and their reef environments are of major importance to better understand ecosystem functioning (Rädecker et al., 2015), the uptake and utilization of $\mathrm{N}$ (this study) should be compared to eutrophication effects on the $\mathrm{N}$ cycle (Y El-Khaled et al., in review).

\section{Conclusions}

Anthropogenic pressures on the Red Sea are constantly increasing (Carvalho et al., 2019) and 60 $\%$ of Red Sea coral reefs are at stake (Burke et al., 2011). We were able to show cascaded, group-specific responses to $\mathrm{N}$ availability and link elemental and isotopic composition to groupspecific nutrient limitations, $\mathrm{N}$ uptake and utilization, and highlight the importance of $\mathrm{P}$ limitations in hard and soft corals. Even over an eight-week $\mathrm{N}$ eutrophication and under high abundance of herbivores, significant uptake and utilization of fertilizer $\mathrm{N}$ was shown particularly for turf algae as strong competitors for space in struggling reef ecosystems. As such, our study corroborates that turf algae can be early indicators for changes and anthropogenic influence (Barott et al., 2012; Roth et al., 2015), reacting faster to eutrophication than hard coral zooxanthellae. As turf algae play a key role in phase shifts, are strong competitors to corals, rapidly take over bare substrates and are highly persistent, their substantial biochemical benefits from $\mathrm{N}$ supply should push coastal management to not only consider limiting future discharges but try to reduce both point-sources and non-point sources of nutrients already in place. Given the increasing coastal development in the central Red Sea, water quality management is challenged to improve future reef states (Gurney et al., 2013; D’Angelo \& Wiedenmann, 2014) and should be on regional agendas for coastal urban development and aquaculture. The context in which eutrophication effects should be seen comprises further local (e.g. fishing pressure and habitat destruction) and global (e.g. warming and ocean acidification) factors to which coastal development adds high nutrient loads on top. Low $\mathrm{N}$ concentrations were shown to be a crucial precondition for coral recovery (Robinson, Wilson \& Graham, 2019) and particularly in the Red Sea the maintaining of oligotrophic conditions could be the key factor and challenge for coral health and resilience to climate change (Hall et al., 2018). 


\section{Author contributions}

483 FR, CW, DBK, and SC planned the research. DBK, FR, YEK, AT and US participated in 484 collection of data. DBK, FR, and CW led data analysis. DBK wrote the manuscript with 485 significant contributions of all authors. All authors read and approved the final manuscript. This 486 research was supported by DFG grant Wi 2677/9-1 to Christian Wild, KAUST baseline funding 487 to Burton H. Jones, and the KAUST VSRP program to Denis B. Karcher. Susana Carvalho is 488 funded by the Saudi Aramco - KAUST Center for Marine Environmental Observations.

\section{Conflict of interest statement}

490 The authors declare that the research was conducted in the absence of any commercial or 491 financial relationships that could be construed as a potential conflict of interest.

\section{Acknowledgements}

493 We are thankful to Marianne Falk for helping in elemental - and isotopic analysis and Nils 494 Rädecker for coral sample processing advice. We were happy to get further support by Pedro 495 Ruiz-Compean (sediment samples), Aislinn Dunne (sediment samples), Sophia Tobler (image 496 editing), Rodrigo Villalobos and João Cúrdia (both field work). 
498

499

500

501

502

503

504

505

506

507

508

509

510

511

512

513

514

515

516

517

518

519

520

\section{References}

Abu-Rizaiza OS, Sarikaya HZ. 1993. Drainage Water Disposal, Jeddah, Saudi Arabia. Journal of Water Resources Planning and Management 119:706-712. DOI: 10.1061/(ASCE)07339496(1993)119:6(706).

Adams C, Frantz J, Bugbee B. 2013. Macro- and micronutrient-release characteristics of three polymer-coated fertilizers: Theory and measurements. Journal of Plant Nutrition and Soil Science 176:76-88. DOI: 10.1002/jpln.201200156.

Airoldi L. 1998. Roles of Disturbance, Sediment Stress, and Substratum Retention on Spatial Dominance in Algal Turf. Ecology 79:2759-2770. DOI: 10.1890/00129658(1998)079[2759:RODSSA]2.0.CO;2.

Al-Farawati R. 2010. Environmental Conditions of the Coastal Waters of Southern Corinche, Jeddah, Eastern Red Sea: Physico-chemical Approach. Australian Journal of Basic and Applied Sciences 4:3324-3337.

Al-Farawati R, El Sayed MAK, Rasul NMA. 2019. Nitrogen, Phosphorus and Organic Carbon in the Saudi Arabian Red Sea Coastal Waters: Behaviour and Human Impact. In: Rasul NMA, Stewart ICF eds. Oceanographic and Biological Aspects of the Red Sea. Cham: Springer International Publishing, 89-104. DOI: 10.1007/978-3-319-99417-8_5.

Aljoufie M, Tiwari A. 2015. Climate Change Adaptions for Urban Water Infrastructure in Jeddah, Kingdom of Saudi Arabia. Journal of Sustainable Development 8:p52. DOI: 10.5539/jsd.v8n3p52.

Al-Sofyani AA, Floos YAM. 2013. Effect of temperature on two reef-building corals Pocillopora damicornis and P. verrucosa in the Red Sea. Oceanologia 55:917-935. DOI: 10.5697/oc.55-4.917. 
521 Baker DM, Jordán-Dahlgren E, Maldonado MA, Harvell CD. 2010. Sea fan corals provide a

522 stable isotope baseline for assessing sewage pollution in the Mexican Caribbean.

523 Limnology and Oceanography 55:2139-2149. DOI: 10.4319/1o.2010.55.5.2139.

Barott KL, Rohwer FL. 2012. Unseen players shape benthic competition on coral reefs. Trends in Microbiology 20:621-628. DOI: 10.1016/j.tim.2012.08.004.

Barott K, Williams G, Vermeij M, Harris J, Smith J, Rohwer F, Sandin S. 2012. Natural history of coral-algae competition across a gradient of human activity in the Line Islands. Marine Ecology Progress Series 460:1-12. DOI: 10.3354/meps09874.

Basaham A, Rifaat A, El-Mamoney M, El-Sayed M. 2009. Re-Evaluation of the Impact of Sewage Disposal on Coastal Sediments of the Southern Corniche, Jeddah, Saudi Arabia. Journal of King Abdulaziz University-Marine Sciences 20:109-126. DOI: 10.4197/Mar.20-1.8.

Bednarz VN, Naumann MS, Niggl W, Wild C. 2012. Inorganic nutrient availability affects organic matter fluxes and metabolic activity in the soft coral genus Xenia. Journal of Experimental Biology 215:3672-3679. DOI: 10.1242/jeb.072884.

Berumen ML, Hoey AS, Bass WH, Bouwmeester J, Catania D, Cochran JEM, Khalil MT, Miyake S, Mughal MR, Spaet JLY, Saenz-Agudelo P. 2013. The status of coral reef ecology research in the Red Sea. Coral Reefs 32:737-748. DOI: 10.1007/s00338-0131055-8.

Berumen ML, Voolstra CR, Daffonchio D, Agusti S, Aranda M, Irigoien X, Jones BH, Morán XAG, Duarte CM. 2019. The Red Sea: Environmental Gradients Shape a Natural Laboratory in a Nascent Ocean. In: Voolstra CR, Berumen ML eds. Coral reefs of the Red Sea. New York, NY: Springer Berlin Heidelberg, 1-10. 
544 Bongiorni L, Shafir S, Angel D, Rinkevich B. 2003. Survival, growth and gonad development of

545

546

547

548

549

550

551

552

553

554

555

556

557

558

559

560

561

562

563

564

565

566

two hermatypic corals subjected to in situ fish-farm nutrient enrichment. Marine Ecology Progress Series 253:137-144. DOI: 10.3354/meps253137.

Burke L, Reytar K, Spalding M, Perry A. 2011. Reefs at risk revisited. World Resources Institute.

Burkepile DE, Shantz AA, Adam TC, Munsterman KS, Speare KE, Ladd MC, Rice MM, Ezzat L, McIlroy S, Wong JCY, Baker DM, Brooks AJ, Schmitt RJ, Holbrook SJ. 2019. Nitrogen Identity Drives Differential Impacts of Nutrients on Coral Bleaching and Mortality. Ecosystems. DOI: 10.1007/s10021-019-00433-2.

Capone D, Dunham S, Horrigan S, Duguay L. 1992. Microbial nitrogen transformations in unconsolidated coral reef sediments. Marine Ecology Progress Series 80:75-88. DOI: $10.3354 /$ meps080075.

Cárdenas A, Meyer F, Schwieder H, Wild C, Gärdes A. 2015. The formation of aggregates in coral reef waters under elevated concentrations of dissolved inorganic and organic carbon: A mesocosm approach. Marine Chemistry 175:47-55. DOI: 10.1016/j.marchem.2015.04.002.

Carpenter KE, Abrar M, Aeby G, Aronson RB, Banks S, Bruckner A, Chiriboga A, Cortes J, Delbeek JC, DeVantier L, Edgar GJ, Edwards AJ, Fenner D, Guzman HM, Hoeksema BW, Hodgson G, Johan O, Licuanan WY, Livingstone SR, Lovell ER, Moore JA, Obura DO, Ochavillo D, Polidoro BA, Precht WF, Quibilan MC, Reboton C, Richards ZT, Rogers AD, Sanciangco J, Sheppard A, Sheppard C, Smith J, Stuart S, Turak E, Veron JEN, Wallace C, Weil E, Wood E. 2008. One-Third of Reef-Building Corals Face Elevated Extinction Risk from Climate Change and Local Impacts. Science 321:560-563. 
DOI: $10.1126 /$ science.1159196.

568 Carpenter EJ, Harvey HR, Fry B, Capone DG. 1997. Biogeochemical tracers of the marine

569 cyanobacterium Trichodesmium. Deep Sea Research Part I: Oceanographic Research

570 Papers 44:27-38. DOI: 10.1016/S0967-0637(96)00091-X.

571 Carvalho S, Kürten B, Krokos G, Hoteit I, Ellis J. 2019. The Red Sea. In: World Seas: an Environmental Evaluation. Elsevier, 49-74. DOI: 10.1016/B978-0-08-100853-9.00004$\mathrm{X}$.

Cook P, Veuger B, Böer S, Middelburg J. 2007. Effect of nutrient availability on carbon and

575

576

577

578

579

580

581

582

583

584

585

586

587

588

589

nitrogen incorporation and flows through benthic algae and bacteria in near-shore sandy sediment. Aquatic Microbial Ecology 49:165-180. DOI: 10.3354/ame01142.

Costa OS, Leão ZMAN, Nimmo M, Attrill MJ. 2000. Nutrification impacts on coral reefs from northern Bahia, Brazil. In: Jones MB, Azevedo JMN, Neto AI, Costa AC, Martins AMF eds. Island, Ocean and Deep-Sea Biology. Dordrecht: Springer Netherlands, 307-315. DOI: $10.1007 / 978-94-017-1982-728$.

Costanzo SD, O’Donohue MJ, Dennison WC, Loneragan NR, Thomas M. 2001. A New Approach for Detecting and Mapping Sewage Impacts. Marine Pollution Bulletin 42:149-156. DOI: 10.1016/S0025-326X(00)00125-9.

Cuet P, Atkinson MJ, Blanchot J, Casareto BE, Cordier E, Falter J, Frouin P, Fujimura H, Pierret C, Susuki Y, Tourrand C. 2011. CNP budgets of a coral-dominated fringing reef at La Réunion, France: coupling of oceanic phosphate and groundwater nitrate. Coral Reefs 30:45-55. DOI: 10.1007/s00338-011-0744-4.

D’Angelo C, Wiedenmann J. 2014. Impacts of nutrient enrichment on coral reefs: new perspectives and implications for coastal management and reef survival. Current Opinion 
in Environmental Sustainability 7:82-93. DOI: 10.1016/j.cosust.2013.11.029.

591 Dunne AFJ. 2018. Monitoring the effects of offshore aquaculture on water quality in the Red Sea. Master's thesis at King Abdullah University of Science and Technology, Thuwal, Saudi Arabia.

Duprey NN, Yasuhara M, Baker DM. 2016. Reefs of tomorrow: eutrophication reduces coral biodiversity in an urbanized seascape. Global Change Biology 22:3550-3565. DOI: carbonate sands. Continental Shelf Research 77:69-80. DOI: 10.1016/j.csr.2014.02.002. 10.1111/gcb.13432.

Erler DV, Santos IR, Eyre BD. 2014. Inorganic nitrogen transformations within permeable

Eyre BD, Glud RN, Patten N. 2008. Mass coral spawning: A natural large-scale nutrient addition experiment. Limnology and Oceanography 53:997-1013. DOI:

Ezzat L, Maguer J-F, Grover R, Ferrier-Pagès C. 2016. Limited phosphorus availability is the Achilles heel of tropical reef corals in a warming ocean. Scientific Reports 6:31768. DOI: $10.1038 /$ srep31768.

Ezzat L, Maguer J, Grover R, Rottier C, Tremblay P, Ferrier-Pagès C. 2019. Nutrient starvation impairs the trophic plasticity of reef-building corals under ocean warming. Functional Ecology 33:643-653. DOI: 10.1111/1365-2435.13285.

Fabricius KE. 2005. Effects of terrestrial runoff on the ecology of corals and coral reefs: review and synthesis. Marine Pollution Bulletin 50:125-146. DOI: 10.1016/j.marpolbul.2004.11.028.

Fabricius K, De'ath G, McCook L, Turak E, Williams DMcB. 2005. Changes in algal, coral and fish assemblages along water quality gradients on the inshore Great Barrier Reef. Marine 
614 Falkenberg LJ, Russell BD, Connell SD. 2013. Contrasting resource limitations of marine primary producers: implications for competitive interactions under enriched $\mathrm{CO} 2$ and nutrient regimes. Oecologia 172:575-583. DOI: 10.1007/s00442-012-2507-5.

Falkowski PG, Dubinsky Z, Muscatine L, McCloskey L. 1993. Population Control in Symbiotic

619

620

621

622

623

624

625

626

627

628

629

630

631

632

633

634

635 Corals. BioScience 43:606-611. DOI: 10.2307/1312147.

Ferrier-Pagès C, Gattuso J-P, Dallot S, Jaubert J. 2000. Effect of nutrient enrichment on growth and photosynthesis of the zooxanthellate coral Stylophora pistillata. Coral Reefs 19:103113. DOI: $10.1007 / \mathrm{s} 003380000078$.

Ferrier-Pagès C, Godinot C, D’Angelo C, Wiedenmann J, Grover R. 2016. Phosphorus metabolism of reef organisms with algal symbionts. Ecological Monographs 86:262-277. DOI: $10.1002 / \mathrm{ecm} .1217$.

Ferrier-Pagès C, Schoelzke V, Jaubert J, Muscatine L, Hoegh-Guldberg O. 2001. Response of a scleractinian coral, Stylophora pistillata, to iron and nitrate enrichment. Journal of Experimental Marine Biology and Ecology 259:249-261. DOI: 10.1016/S00220981(01)00241-6.

Godinot C, Grover R, Allemand D, Ferrier-Pages C. 2011. High phosphate uptake requirements of the scleractinian coral Stylophora pistillata. Journal of Experimental Biology 214:2749-2754. DOI: 10.1242/jeb.054239.

Goldman JC. 1986. On phytoplankton growth rates and particulate C: N: P ratios at low light1. Limnology and Oceanography 31:1358-1363. DOI: 10.4319/1o.1986.31.6.1358.

Gorgula SoniaK, Connell SeanD. 2004. Expansive covers of turf-forming algae on humandominated coast: the relative effects of increasing nutrient and sediment loads. Marine 
637 Grottoli AG, Tchernov D, Winters G. 2017. Physiological and Biogeochemical Responses of

638

639

640

641

642

643

644

645

646

647

648

649

650

651

652

653

654

655

656

657

658 Super-Corals to Thermal Stress from the Northern Gulf of Aqaba, Red Sea. Frontiers in Marine Science 4:215. DOI: 10.3389/fmars.2017.00215.

Grover R, Maguer J-F, Allemand D, Ferrier-Pagés C. 2003. Nitrate uptake in the scleractinian coral Stylophora pistillata. Limnology and Oceanography 48:2266-2274. DOI: 10.4319/1o.2003.48.6.2266.

Grover R, Maguer J-F, Reynaud-Vaganay S, Ferrier-Pagès C. 2002. Uptake of ammonium by the scleractinian coral Stylophora pistillata : Effect of feeding, light, and ammonium concentrations. Limnology and Oceanography 47:782-790. DOI: 10.4319/1o.2002.47.3.0782.

Gurney GG, Melbourne-Thomas J, Geronimo RC, Aliño PM, Johnson CR. 2013. Modelling Coral Reef Futures to Inform Management: Can Reducing Local-Scale Stressors Conserve Reefs under Climate Change? PLOS ONE 8:e80137. DOI: 10.1371/journal.pone.0080137.

den Haan J, Huisman J, Brocke HJ, Goehlich H, Latijnhouwers KRW, van Heeringen S, Honcoop SAS, Bleyenberg TE, Schouten S, Cerli C, Hoitinga L, Vermeij MJA, Visser PM. 2016. Nitrogen and phosphorus uptake rates of different species from a coral reef community after a nutrient pulse. Scientific Reports 6:28821. DOI: 10.1038/srep28821.

Haas A, Al-Zibdah M, Wild C. 2009. Effect of inorganic and organic nutrient addition on coralalgae assemblages from the Northern Red Sea. Journal of Experimental Marine Biology and Ecology 380:99-105. DOI: 10.1016/j.jembe.2009.09.005.

Haas AF, Nelson CE, Wegley Kelly L, Carlson CA, Rohwer F, Leichter JJ, Wyatt A, Smith JE. 
659

660

661

662

663

664

665

666

667

668

669

670

671

672

673

674

675

676

677

678

679

680

681

2011. Effects of Coral Reef Benthic Primary Producers on Dissolved Organic Carbon and Microbial Activity. PLoS ONE 6:e27973. DOI: 10.1371/journal.pone.0027973.

Hall ER, Muller EM, Goulet T, Bellworthy J, Ritchie KB, Fine M. 2018. Eutrophication may compromise the resilience of the Red Sea coral Stylophora pistillata to global change. Marine Pollution Bulletin 131:701-711. DOI: 10.1016/j.marpolbul.2018.04.067.

Harrison P, Ward S. 2001. Elevated levels of nitrogen and phosphorus reduce fertilisation success of gametes from scleractinian reef corals. Marine Biology 139:1057-1068. DOI: $10.1007 / \mathrm{s} 002270100668$.

Hatcher BG, Larkum AWD. 1983. An experimental analysis of factors controlling the standing crop of the epilithic algal community on a coral reef. Journal of Experimental Marine Biology and Ecology 69:61-84. DOI: 10.1016/0022-0981(83)90172-7.

Hecky RE, Campbell P, Hendzel LL. 1993. The stoichiometry of carbon, nitrogen, and phosphorus in particulate matter of lakes and oceans. Limnology and Oceanography 38:709-724. DOI: 10.4319/1o.1993.38.4.0709.

Hillebrand H, Sommer U. 1999. The nutrient stoichiometry of benthic microalgal growth: Redfield proportions are optimal. Limnology and Oceanography 44:440-446. DOI: 10.4319/1o.1999.44.2.0440.

Hoegh-Guldberg O, Mumby PJ, Hooten AJ, Steneck RS, Greenfield P, Gomez E, Harvell CD, Sale PF, Edwards AJ, Caldeira K, Knowlton N, Eakin CM, Iglesias-Prieto R, Muthiga N, Bradbury RH, Dubi A, Hatziolos ME. 2007. Coral Reefs Under Rapid Climate Change and Ocean Acidification. Science 318:1737-1742. DOI: 10.1126/science.1152509.

Hoegh-Guldberg O, Muscatine L, Goiran C, Siggaard D, Marion G. 2004. Nutrient-induced perturbations to $\delta^{13} \mathrm{C}$ and $\delta^{15} \mathrm{~N}$ in symbiotic dinoflagellates and their coral hosts. Marine 
Ecology Progress Series 280:105-114. DOI: 10.3354/meps280105.

683 Hozumi A, Hong P, Kaartvedt S, Røstad A, Jones B. 2018. Water quality, seasonality, and

684 trajectory of an aquaculture-wastewater plume in the Red Sea. Aquaculture Environment 685 Interactions 10:61-77. DOI: 10.3354/aei00254.

686

687

688

689

690

691

692

693

694

695

696

697

698

699

700

701

702

703

704

Hughes TP, Anderson KD, Connolly SR, Heron SF, Kerry JT, Lough JM, Baird AH, Baum JK, Berumen ML, Bridge TC, Claar DC, Eakin CM, Gilmour JP, Graham NAJ, Harrison H, Hobbs J-PA, Hoey AS, Hoogenboom M, Lowe RJ, McCulloch MT, Pandolfi JM, Pratchett M, Schoepf V, Torda G, Wilson SK. 2018. Spatial and temporal patterns of mass bleaching of corals in the Anthropocene. Science 359:80. DOI:

10.1126/science.aan8048.

Jessen C, Roder C, Villa Lizcano JF, Voolstra CR, Wild C. 2013a. In-Situ Effects of Simulated Overfishing and Eutrophication on Benthic Coral Reef Algae Growth, Succession, and Composition in the Central Red Sea. PLoS ONE 8:e66992. DOI:

10.1371/journal.pone.0066992.

Jessen C, Villa Lizcano JF, Bayer T, Roder C, Aranda M, Wild C, Voolstra CR. 2013b. In-situ Effects of Eutrophication and Overfishing on Physiology and Bacterial Diversity of the Red Sea Coral Acropora hemprichii. PLoS ONE 8:e62091. DOI: 10.1371/journal.pone.0062091.

Johnson C, Klumpp D, Field J, Bradbury R. 1995. Carbon flux on coral reefs: effects of large shifts in community structure. Marine Ecology Progress Series 126:123-143. DOI: $10.3354 /$ meps 126123 .

Karl D, Michaels A, Bergman B, Capone D, Carpenter E, Letelier R, Lipschultz F, Paerl H, Sigman D, Stal L. 2002. Dinitrogen fixation in the world's oceans. In: Boyer EW, 
705

706

707

708

709

710

711

712

713

714

715

716

717

718

719

720

721

722

723

724

725

726

727

Howarth RW eds. The Nitrogen Cycle at Regional to Global Scales. Dordrecht: Springer Netherlands, 47-98. DOI: 10.1007/978-94-017-3405-9_2.

Kendall C, Elliott EM, Wankel SD. 2007. Tracing anthropogenic inputs of nitrogen to ecosystems. In: Michener RH, Lajtha K eds. Stable isotopes in ecology and environmental science. Malden, MA: Blackwell Pub, 375-449.

Kinsey DW, Davies PJ. 1979. Effects of elevated nitrogen and phosphorus on coral reef growth. Limnology and Oceanography 24:935-940. DOI: 10.4319/1o.1979.24.5.0935.

Koop K, Booth D, Dennison W, Erdmann M, Jones GB, Larkum AWD, O’Neil J, Steven A, Tentori E, Ward S, Williamson J, Yellowlees D. 2001. ENCORE: The Effect of Nutrient Enrichment on Coral Reefs. Synthesis of Results and Conclusions. Marine Pollution Bulletin 42:30.

Kopp C, Pernice M, Domart-Coulon I, Djediat C, Spangenberg JE, Alexander DTL, Hignette M, Meziane T, Meibom A. 2013. Highly Dynamic Cellular-Level Response of Symbiotic Coral to a Sudden Increase in Environmental Nitrogen. mBio 4:e00052-13. DOI: 10.1128/mBio.00052-13.

Kürten B, Al-Aidaroos AM, Struck U, Khomayis HS, Gharbawi WY, Sommer U. 2014. Influence of environmental gradients on $\mathrm{C}$ and $\mathrm{N}$ stable isotope ratios in coral reef biota of the Red Sea, Saudi Arabia. Journal of Sea Research 85:379-394. DOI: 10.1016/j.seares.2013.07.008.

Kürten B, Khomayis HS, Devassy R, Audritz S, Sommer U, Struck U, El-Sherbiny MM, AlAidaroos AM. 2015. Ecohydrographic constraints on biodiversity and distribution of phytoplankton and zooplankton in coral reefs of the Red Sea, Saudi Arabia. Marine Ecology 36:1195-1214. DOI: 10.1111/maec.12224. 
728 Lapointe BE. 1987. Phosphorus- and nitrogen-limited photosynthesis and growth of Gracilaria

729

730

731

732

733

734

735

736

737

738

739

740

741

742

743

744

745

746

747

748

749

750 tikvahiae (Rhodophyceae) in the Florida Keys: an experimental field study. Marine Biology 93:561-568. DOI: 10.1007/BF00392794.

Lapointe BE. 1997. Nutrient thresholds for bottom-up control of macroalgal blooms on coral reefs in Jamaica and southeast Florida. Limnology and Oceanography 42:1119-1131. DOI: 10.4319/1o.1997.42.5_part_2.1119.

Lapointe BE, Barile PJ, Littler MM, Littler DS, Bedford BJ, Gasque C. 2005. Macroalgal blooms on southeast Florida coral reefs I. Nutrient stoichiometry of the invasive green alga Codium isthmocladum in the wider Caribbean indicates nutrient enrichment. Harmful Algae:14.

Lapointe BE, Brewton RA, Herren LW, Porter JW, Hu C. 2019. Nitrogen enrichment, altered stoichiometry, and coral reef decline at Looe Key, Florida Keys, USA: a 3-decade study. Marine Biology 166:108. DOI: 10.1007/s00227-019-3538-9.

Lapointe BE, Littler MM, Littler DS. 1992. Nutrient Availability to Marine Macroalgae in Siliciclastic versus Carbonate-Rich Coastal Waters. Estuaries 15:75. DOI: $10.2307 / 1352712$

Lesser M, Falcón L, Rodríguez-Román A, Enríquez S, Hoegh-Guldberg O, Iglesias-Prieto R. 2007. Nitrogen fixation by symbiotic cyanobacteria provides a source of nitrogen for the scleractinian coral Montastraea cavernosa. Marine Ecology Progress Series 346:143152. DOI: $10.3354 /$ meps 07008 .

Loya Y, Lubinevsky H, Rosenfeld M, Kramarsky-Winter E. 2004. Nutrient enrichment caused by in situ fish farms at Eilat, Red Sea is detrimental to coral reproduction. Marine Pollution Bulletin 49:344-353. DOI: 10.1016/j.marpolbul.2004.06.011. 
751 McCook LJ. 1999. Macroalgae, nutrients and phase shifts on coral reefs: scientific issues and

752 management consequences for the Great Barrier Reef. Coral Reefs 18:357-367. DOI:

753 $10.1007 / \mathrm{s} 003380050213$.

754

755

756

757

758

759

760

761

762

763

764

765

766

767

768

769

770

771

772

773

McManus JW, Polsenberg JF. 2004. Coral-algal phase shifts on coral reefs: Ecological and environmental aspects. Progress in Oceanography 60:263-279. DOI: 10.1016/j.pocean.2004.02.014.

Millero F, Huang F, Zhu X, Liu X, Zhang J-Z. 2001. Adsorption and Desorption of Phosphate on Calcite and Aragonite in Seawater. Aquatic Geochemistry 7:33-56.

Ministry of Health. 2017. Annual Statistical Book 2017 G. Kingdom of Saudi Arabia. https://www.moh.gov.sa/en/Ministry/Statistics/book/Documents/ANNUALSTATISTICAL-BOOK-1438H.pdf (Accessed: 30/04/2019).

Miyajima T, Suzumura M, Umezawa Y, Koike I. 2001. Microbiological nitrogen transformation in carbonate sediments of a coral-reef lagoon and associated seagrass beds. Marine Ecology Progress Series 217:273-286. DOI: 10.3354/meps217273.

Mohamed ZA, Mesaad I. 2007. First report on Noctiluca scintillans blooms in the Red Sea o $\square$ the coasts of Saudi Arabia: consequences of eutrophication. Oceanologia 49:337-351.

Morris LA, Voolstra CR, Quigley KM, Bourne DG, Bay LK. 2019. Nutrient Availability and Metabolism Affect the Stability of Coral-Symbiodiniaceae Symbioses. Trends in Microbiology 27:678-689. DOI: 10.1016/j.tim.2019.03.004.

Müller-Navarra DC. 2008. Food Web Paradigms: The Biochemical View on Trophic Interactions. International Review of Hydrobiology 93:489-505. DOI: 10.1002/iroh.200711046.

Muller-Parker G, Cook CB, D’Elia CF. 1994. Elemental composition of the coral Pocillopora 
damicornis exposed to elevated seawater ammonium. Pacific Science 48:234-246.

775 Naumann MS, Bednarz VN, Ferse SCA, Niggl W, Wild C. 2015. Monitoring of coastal coral

776

777

778

779

780

781

782

783

784

785

786

787

788

789

790

791

792

793

794

795

796 reefs near Dahab (Gulf of Aqaba, Red Sea) indicates local eutrophication as potential cause for change in benthic communities. Environmental Monitoring and Assessment 187:44. DOI: $10.1007 / \mathrm{s} 10661-014-4257-9$.

Norström A, Nyström M, Lokrantz J, Folke C. 2009. Alternative states on coral reefs: beyond coral-macroalgal phase shifts. Marine Ecology Progress Series 376:295-306. DOI: 10.3354/meps07815.

Odum HT, Odum EP. 1955. Trophic Structure and Productivity of a Windward Coral Reef Community on Eniwetok Atoll. Ecological Monographs 25:291-320. DOI: $10.2307 / 1943285$.

O’Neil JM, Capone DG. 2008. Nitrogen Cycling in Coral Reef Environments. In: Nitrogen in the Marine Environment. Elsevier, 949-989. DOI: 10.1016/B978-0-12-372522-6.00021-9.

O’Reilly CM, Hecky RE, Cohen AS, Plisnier P-D. 2002. Interpreting stable isotopes in food webs: Recognizing the role of time averaging at different trophic levels. Limnology and Oceanography 47:306-309. DOI: 10.4319/1o.2002.47.1.0306.

Pearman JK, Afandi F, Hong P, Carvalho S. 2018. Plankton community assessment in anthropogenic-impacted oligotrophic coastal regions. Environmental Science and Pollution Research 25:31017-31030. DOI: 10.1007/s11356-018-3072-1.

Pearman JK, Ellis J, Irigoien X, Sarma YVB, Jones BH, Carvalho S. 2017. Microbial planktonic communities in the Red Sea: high levels of spatial and temporal variability shaped by nutrient availability and turbulence. Scientific Reports 7:6611. DOI: 10.1038/s41598017-06928-z. 
797 Peña-García D, Ladwig N, Turki AJ, Mudarris MS. 2014. Input and dispersion of nutrients from 798 the Jeddah Metropolitan Area, Red Sea. Marine Pollution Bulletin 80:41-51. DOI:

799

800

801

802

803

804

805

806

807

808

809

810

811

812

813

814

815

816

817

818

819 10.1016/j.marpolbul.2014.01.052.

Pernice M, Meibom A, Van Den Heuvel A, Kopp C, Domart-Coulon I, Hoegh-Guldberg O, Dove S. 2012. A single-cell view of ammonium assimilation in coral-dinoflagellate symbiosis. The ISME Journal 6:1314-1324. DOI: 10.1038/ismej.2011.196.

R Core Team. 2017. R: A language and environment for statistical computing. Vienna, Austria: R Foundation for Statistical Computing.

Rädecker N, Pogoreutz C, Voolstra CR, Wiedenmann J, Wild C. 2015. Nitrogen cycling in corals: the key to understanding holobiont functioning? Trends in Microbiology 23:490497. DOI: 10.1016/j.tim.2015.03.008.

Raitsos DE, Pradhan Y, Brewin RJW, Stenchikov G, Hoteit I. 2013. Remote Sensing the Phytoplankton Seasonal Succession of the Red Sea. PLoS ONE 8:e64909. DOI: 10.1371/journal.pone.0064909.

Rasheed M, Badran MI, Huettel M. 2003. Particulate matter filtration and seasonal nutrient dynamics in permeable carbonate and silicate sands of the Gulf of Aqaba, Red Sea. Coral Reefs 22:167-177. DOI: 10.1007/s00338-003-0300-y.

Risk MJ, Lapointe BE, Sherwood OA, Bedford BJ. 2009a. The use of $\delta^{15} \mathrm{~N}$ in assessing sewage stress on coral reefs. Marine Pollution Bulletin 58:793-802. DOI: 10.1016/j.marpolbul.2009.02.008.

Risk M, Sherwood O, Nairn R, Gibbons C. 2009b. Tracking the record of sewage discharge off Jeddah, Saudi Arabia, since 1950, using stable isotope records from antipatharians. Marine Ecology Progress Series 397:219-226. DOI: 10.3354/meps08414. 
820 Rix L, Bednarz V, Cardini U, van Hoytema N, Al-Horani F, Wild C, Naumann M. 2015.

821 Seasonality in dinitrogen fixation and primary productivity by coral reef framework

822

823 substrates from the northern Red Sea. Marine Ecology Progress Series 533:79-92. DOI:

824

825

826

827

828

829

830

831

832

833

834

835

836

837

838

Rix L, de Goeij J, van Oevelen D, Struck U, Al-Horani F, Wild C, Naumann M. 2018. Reef 10.3354/meps11383.

10.3354/meps11383.

Rix L, de Goeij J, van Oevelen D, Struck U, Al-Horani F, Wild C, Naumann M. 2018. Reef sponges facilitate the transfer of coral-derived organic matter to their associated fauna via the sponge loop. Marine Ecology Progress Series 589:85-96. DOI: 10.3354/meps 12443.

Roach TNF, Abieri ML, George EE, Knowles B, Naliboff DS, Smurthwaite CA, Kelly LW, Haas AF, Rohwer FL. 2017. Microbial bioenergetics of coral-algal interactions. PeerJ 5:e3423. DOI: $10.7717 /$ peerj.3423.

Roberts CM. 2002. Marine Biodiversity Hotspots and Conservation Priorities for Tropical Reefs. Science 295:1280-1284. DOI: 10.1126/science.1067728.

Robinson JPW, Wilson SK, Graham NAJ. 2019. Abiotic and biotic controls on coral recovery 16 years after mass bleaching. Coral Reefs. DOI: 10.1007/s00338-019-01831-7.

Rolff C. 2000. Seasonal variation in $\mathrm{d} 13 \mathrm{C}$ and d $15 \mathrm{~N}$ of size-fractionated plankton at a coastal station in the northern Baltic proper. Marine Ecology Progress Series Vol. 203:47-65.

Rosset S, Wiedenmann J, Reed AJ, D’Angelo C. 2017. Phosphate deficiency promotes coral bleaching and is reflected by the ultrastructure of symbiotic dinoflagellates. Marine Pollution Bulletin 118:180-187. DOI: 10.1016/j.marpolbul.2017.02.044.

Roth F, Saalmann F, Thomson T, Coker DJ, Villalobos R, Jones BH, Wild C, Carvalho S. 2018. Coral reef degradation affects the potential for reef recovery after disturbance. Marine Environmental Research 142:48-58. DOI: 10.1016/j.marenvres.2018.09.022.

Roth F, Stuhldreier I, Sánchez-Noguera C, Morales-Ramírez Á, Wild C. 2015. Effects of 
843

844

845

846

847

848

849

850

851

852

853

854

855

856

857

858

859

860

861

862

863

864

865

simulated overfishing on the succession of benthic algae and invertebrates in an upwelling-influenced coral reef of Pacific Costa Rica. Journal of Experimental Marine Biology and Ecology 468:55-66. DOI: 10.1016/j.jembe.2015.03.018.

Roth F, Wild C, Carvalho S, Rädecker N, Voolstra CR, Kürten B, Anlauf H, El-Khaled YC, Carolan R, Jones BH. 2019. An in situ approach for measuring biogeochemical fluxes in structurally complex benthic communities. Methods in Ecology and Evolution 10:712725. DOI: 10.1111/2041-210X.13151.

Russell BD, Thompson J-AI, Falkenberg LJ, Connell SD. 2009. Synergistic effects of climate change and local stressors: $\mathrm{CO}_{2}$ and nutrient-driven change in subtidal rocky habitats. Global Change Biology 15:2153-2162. DOI: 10.1111/j.1365-2486.2009.01886.x.

Sawall Y, Al-Sofyani A, Banguera-Hinestroza E, Voolstra CR. 2014a. Spatio-Temporal Analyses of Symbiodinium Physiology of the Coral Pocillopora verrucosa along LargeScale Nutrient and Temperature Gradients in the Red Sea. PLoS ONE 9:e103179. DOI: 10.1371/journal.pone.0103179.

Sawall Y, Al-Sofyani A, Kürten B, Al-Aidaroos A, Hoang Xuan B, Marimuthu N, Khomayis H, Sommer U, Gharbawi W, Wahl M. 2014b. Coral Communities, in Contrast to Fish Communities, Maintain a High Assembly Similarity along the Large Latitudinal Gradient along the Saudi Red Sea Coast. Journal of Ecosystem \& Ecography s4 003. DOI: 10.4172/2157-7625.S4-003.

Sawall Y, Teichberg MC, Seemann J, Litaay M, Jompa J, Richter C. 2011. Nutritional status and metabolism of the coral Stylophora subseriata along a eutrophication gradient in Spermonde Archipelago (Indonesia). Coral Reefs 30:841-853. DOI: 10.1007/s00338011-0764-0. 
866 Shantz AA, Burkepile DE. 2014. Context-dependent effects of nutrient loading on the coral-

867 algal mutualism. Ecology 95:1995-2005. DOI: 10.1890/13-1407.1.

868 Silbiger NJ, Nelson CE, Remple K, Sevilla JK, Quinlan ZA, Putnam HM, Fox MD, Donahue

869 MJ. 2018. Nutrient pollution disrupts key ecosystem functions on coral reefs.

870 Proceedings of the Royal Society B: Biological Sciences 285:20172718. DOI:

871 10.1098/rspb.2017.2718.

872 009-1546-Z.

Smith J, Smith C, Hunter C. 2001. An experimental analysis of the effects of herbivory and nutrient enrichment on benthic community dynamics on a Hawaiian reef. Coral Reefs water motion on the coral Pocillopora damicornis. Pacific Science 45:299-307.

Sterner RW, Elser JJ. 2002. Ecological stoichiometry: the biology of elements from molecules to 19:332-342. DOI: 10.1007/s003380000124.

Stambler N, Popper N, Dubinsky ZVY, Stimson J. 1991. Effects of nutrient enrichment and the biosphere. Princeton University Press.

Stimson J. 1997. The annual cycle of density of zooxanthellae in the tissues of field and laboratory-held Pocillopora damicornis (Linnaeus). Journal of Experimental Marine Biology and Ecology. 214:35-48.

Stuhldreier I, Bastian P, Schönig E, Wild C. 2015. Effects of simulated eutrophication and overfishing on algae and invertebrate settlement in a coral reef of Koh Phangan, Gulf of Thailand. Marine Pollution Bulletin 92:35-44. DOI: 10.1016/j.marpolbul.2015.01.007.

Swart PK, Saied A, Lamb K. 2005. Temporal and spatial variation in the $\delta^{15} \mathrm{~N}$ and $\delta^{13} \mathrm{C}$ of coral 
tissue and zooxanthellae in Montastraea faveolata collected from the Florida reef tract. Limnology and Oceanography 50:1049-1058. DOI: 10.4319/1o.2005.50.4.1049.

891

892

893

894

895

896

897

898

899

900

901

902

903

904

905

906

907

908

909

910

911

Tanaka Y, Grottoli A, Matsui Y, Suzuki A, Sakai K. 2017. Effects of nitrate and phosphate availability on the tissues and carbonate skeleton of scleractinian corals. Marine Ecology Progress Series 570:101-112. DOI: 10.3354/meps12079.

Tanaka Y, Miyajima T, Koike I, Hayashibara T, Ogawa H. 2006. Translocation and conservation of organic nitrogen within the coral-zooxanthella symbiotic system of Acropora pulchra, as demonstrated by dual isotope-labeling techniques. Journal of Experimental Marine Biology and Ecology 336:110-119. DOI: 10.1016/j.jembe.2006.04.011.

Tilstra A, Bednarz V, Cardini U, van Hoytema N, Al-Rshaidat M, Wild C. 2017. Seasonality affects dinitrogen fixation associated with two common macroalgae from a coral reef in the northern Red Sea. Marine Ecology Progress Series 575:69-80. DOI: $10.3354 /$ meps 12206 .

Tribble GW, Sansone FJ, Smith SV. 1990. Stoichiometric modeling of carbon diagenesis within a coral reef framework. Geochimica et Cosmochimica Acta 54:2439-2449. DOI: 10.1016/0016-7037(90)90231-9.

Vermeij MJA, van Moorselaar I, Engelhard S, Hörnlein C, Vonk SM, Visser PM. 2010. The Effects of Nutrient Enrichment and Herbivore Abundance on the Ability of Turf Algae to Overgrow Coral in the Caribbean. PLoS ONE 5:e14312. DOI: 10.1371/journal.pone.0014312.

Vega Thurber RL, Burkepile DE, Fuchs C, Shantz AA, McMinds R, Zaneveld JR. 2014. Chronic nutrient enrichment increases prevalence and severity of coral disease and bleaching. Global Change Biology 20:544-554. DOI: 10.1111/gcb.12450. 
912 Wall CB, Ritson-Williams R, Popp BN, Gates RD. 2019. Spatial variation in the biochemical 913 and isotopic composition of corals during bleaching and recovery. Limnology and 914 Oceanography:Ino.11166. DOI: 10.1002/lno.11166.

915 Wegley L, Edwards R, Rodriguez-Brito B, Liu H, Rohwer F. 2007. Metagenomic analysis of the 916 microbial community associated with the coral Porites astreoides. Environmental 917 Microbiology 9:2707-2719. DOI: 10.1111/j.1462-2920.2007.01383.x.

918 Wheeler GS. 2003. Minimal increase in larval and adult performance of the biological control agent Oxyops vitiosa when fed Melaleuca quinquenervia leaves of different nitrogen levels. Biological Control 26:109-116. DOI: 10.1016/S1049-9644(02)00129-9.

Wiedenmann J, D’Angelo C, Smith EG, Hunt AN, Legiret F-E, Postle AD, Achterberg EP. 2013. Nutrient enrichment can increase the susceptibility of reef corals to bleaching. Nature Climate Change 3:160-164. DOI: 10.1038/nclimate1661.

924 925

926

927

928

929

930 931 932 933 934
Wild C, Huettel M, Klueter A, Kremb SG, Rasheed MYM, Jørgensen BB. 2004a. Coral mucus functions as an energy carrier and particle trap in the reef ecosystem. Nature 428:66-70. DOI: $10.1038 /$ nature02344.

Wild C, Rasheed M, Werner U, Franke U, Johnstone R, Huettel M. 2004b. Degradation and mineralization of coral mucus in reef environments. Marine Ecology Progress Series 267:159-171. DOI: $10.3354 / \operatorname{meps} 267159$.

Williams S, Carpenter R. 1988. Nitrogen-limited primary productivity of coral reef algal turfs: potential contribution of ammonium excreted by Diadema antillarum. Marine Ecology Progress Series 47:145-152. DOI: 10.3354/meps047145.

Wooldridge SA, Done TJ. 2009. Improved water quality can ameliorate effects of climate change on corals. Ecological Applications 19:1492-1499. DOI: 10.1890/08-0963.1. 
935 Yamamoto M, Kayanne H, Yamamuro M. 2001. Characteristics of organic matter in lagoonal 936 sediments from the Great Barrier Reef. Geochemical Journal 35:385-401. DOI:

937 10.2343/geochemj.35.385.

938 Yamamuro M, Kayanne H, Minagawao M. 1995. Carbon and nitrogen stable isotopes of primary 939 producers in coral reef ecosystems. Limnology and Oceanography 40:617-621. DOI:

$940 \quad 10.4319 / 10.1995 .40 .3 .0617$.

941 Ziegler M, Roder CM, Büchel C, Voolstra CR. 2014. Limits to physiological plasticity of the 942 coral Pocillopora verrucosa from the central Red Sea. Coral Reefs 33:1115-1129. DOI: $943 \quad 10.1007 / \mathrm{s} 00338-014-1192-8$.

944 Ziegler M, Roik A, Porter A, Zubier K, Mudarris MS, Ormond R, Voolstra CR. 2016. Coral 945 microbial community dynamics in response to anthropogenic impacts near a major city in 946 the central Red Sea. Marine Pollution Bulletin 105:629-640. DOI:

947 10.1016/j.marpolbul.2015.12.045. 


\section{Table 1 (on next page)}

Relative benthic cover of functional groups at the experimental reef. Data taken from (Roth et al., 2018) . 
1

\begin{tabular}{l|c} 
Major functional groups & Cover [\%] \\
\hline Filamentous turf algae & 36.8 \\
Hard coral & 28.8 \\
Rubble & 10.2 \\
Biogenic rock & 8.7 \\
Soft coral & 8.5 \\
Sediment & 6.0 \\
Tridacna sp. & 0.7 \\
Macroalgae & 0.4
\end{tabular}


Figure 1

Example of a manipulated in-situ community surrounded by four pins with attached fertilizer (Osmocote ${ }^{\circledR}$ ) bags, photo: Florian Roth. 


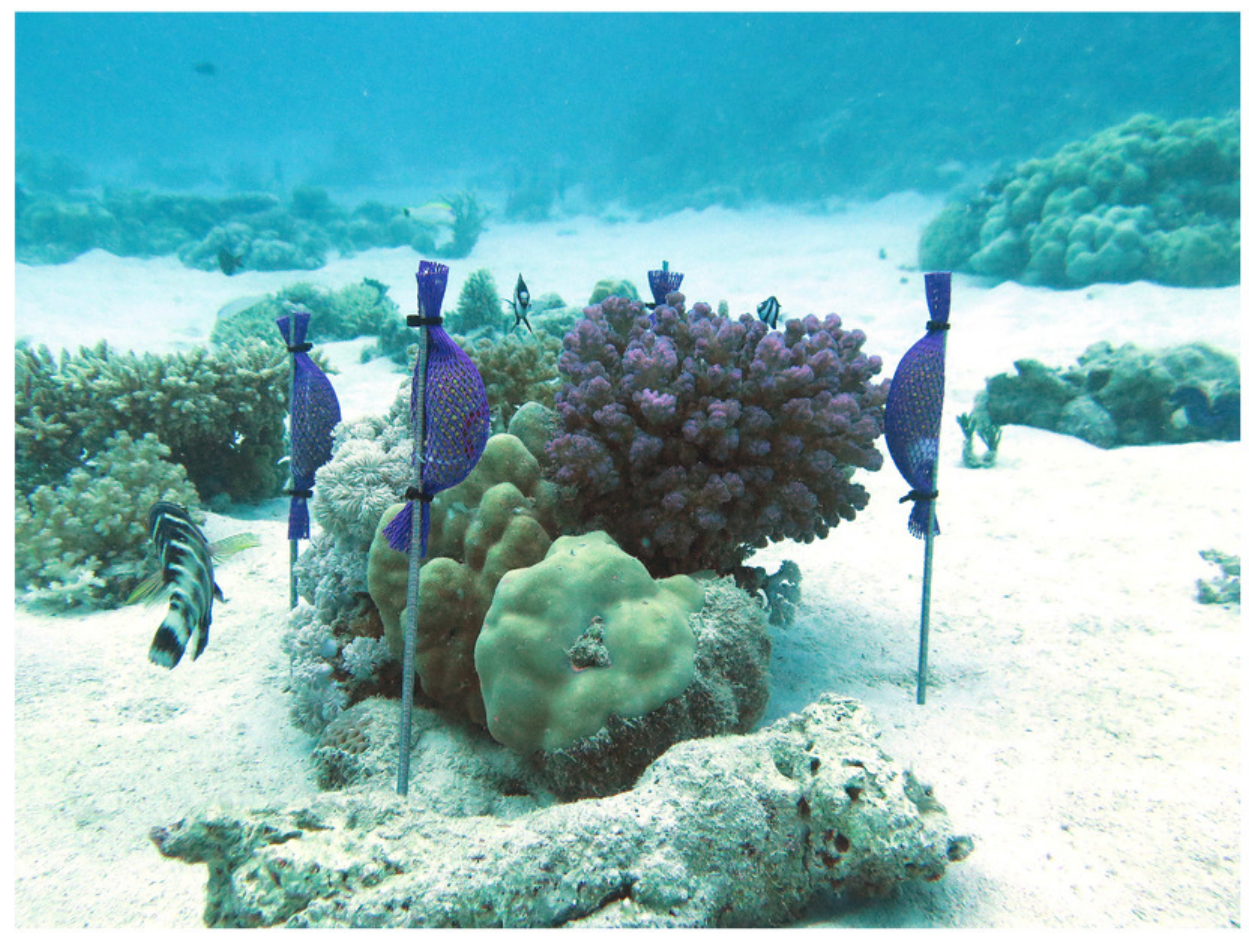


Figure 2

Dissolved inorganic nitrogen (DIN) concentrations at experimental communities (red, last data point extrapolated) and of background sea water (grey) over time of in-situ manipulation.

Black arrows symbolize introduction and renewal of fertilizer.

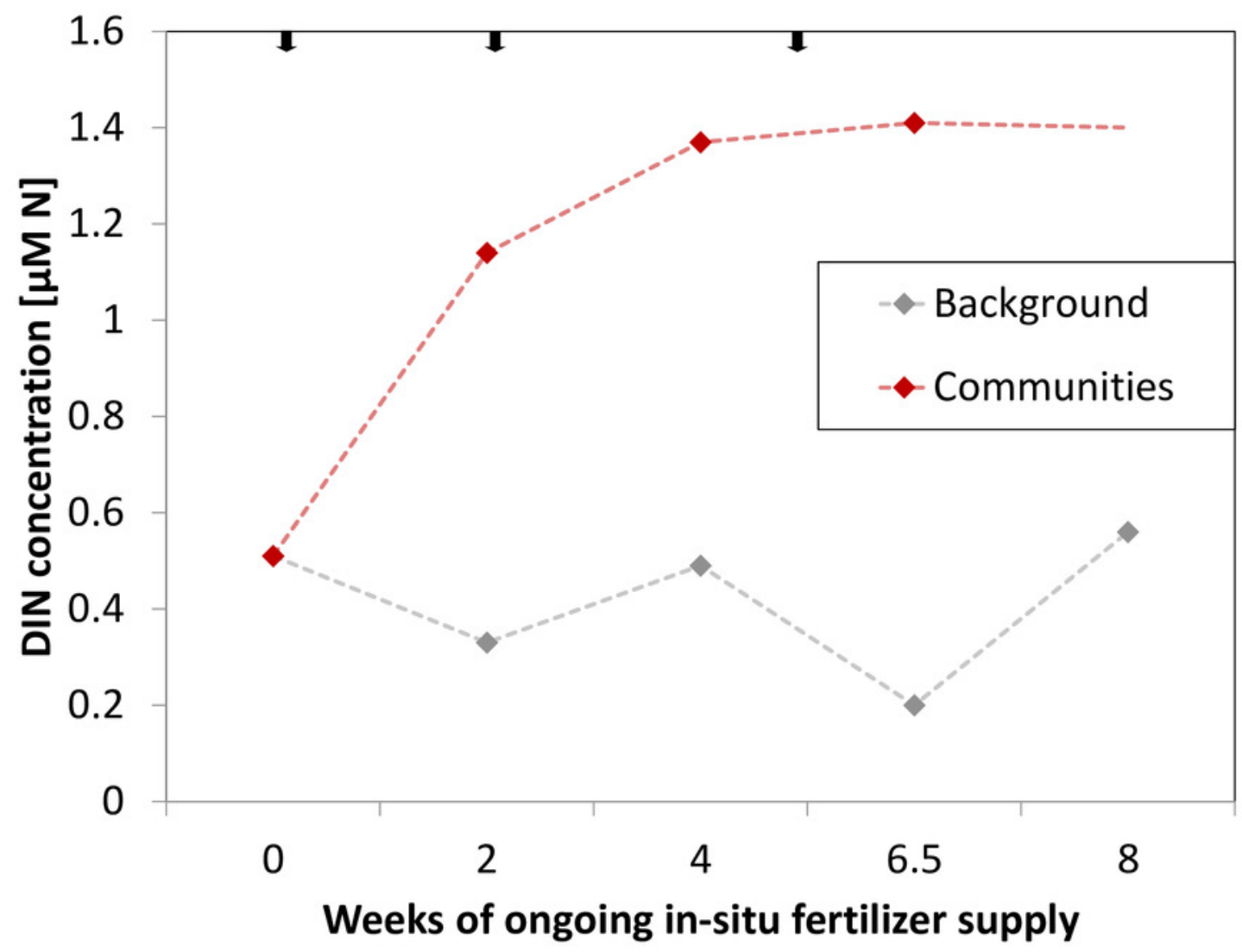




\section{Figure 3}

Nitrogen $(\mathrm{N})$ and carbon elemental and $\mathrm{N}$ isotopic composition of major functional groups before (grey), without (blue) and after eight weeks in-situ eutrophication (red).

Investigated groups are turf algae, Pocillopora cf. verrucosa zooxanthellae („zoox.“) and tissue, Xeniidae and sediments. Eight replicates per boxplot. A: nitrogen isotopes $\left({ }^{15} \mathrm{~N}\right), \mathrm{B}$ : nitrogen content $(\% \mathrm{~N}), \mathrm{C}$ : organic carbon content $\left(\% \mathrm{C}_{\text {org }}\right)$, D: organic carbon to nitrogen ratio $\left(\mathrm{C}_{\text {org }} / \mathrm{N}\right)$. Asterisks indicate significant differences $(* p<0.05, * * p<0.005, * * *<0.001)$. 

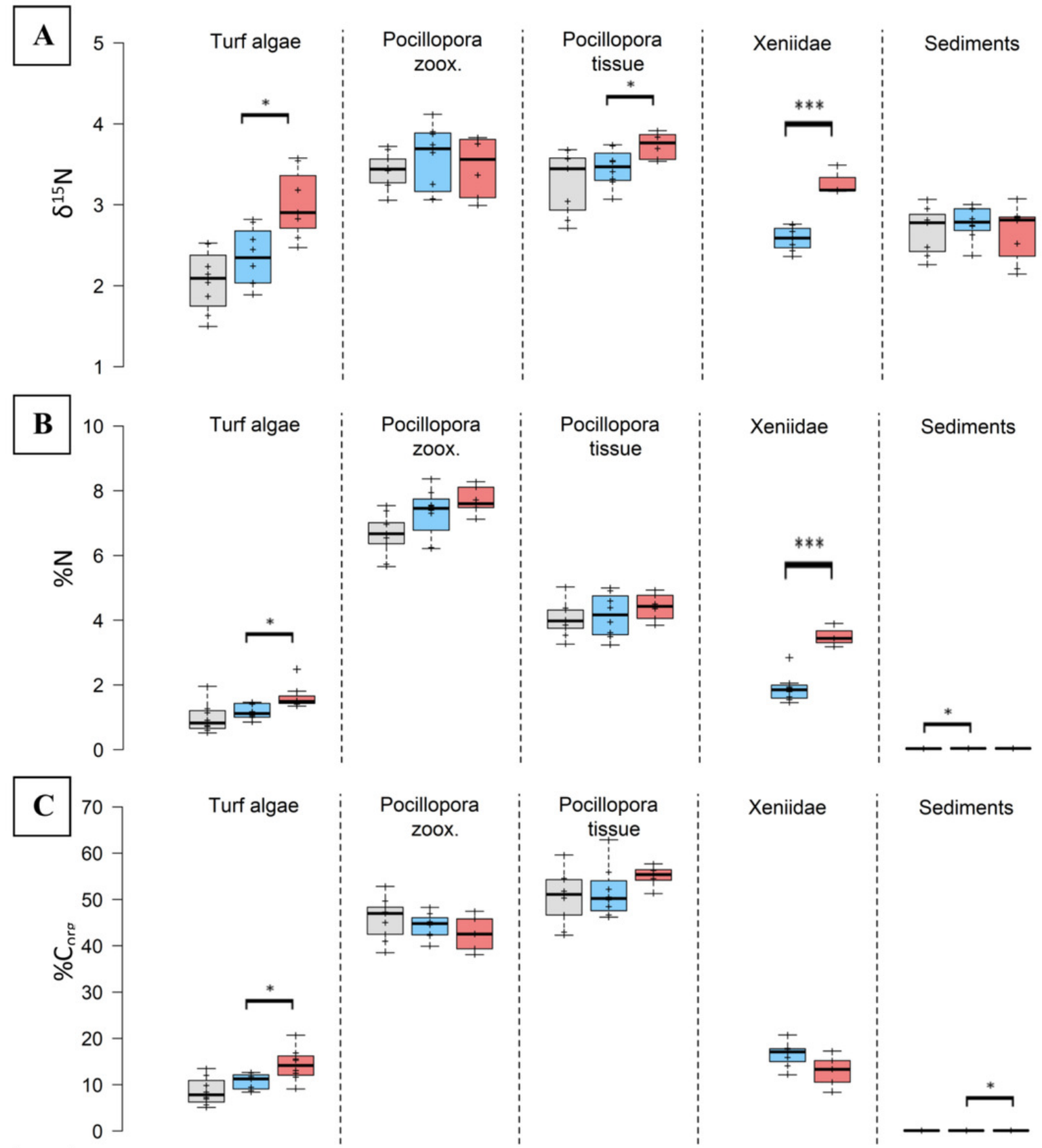

Xeniidae

Sediments
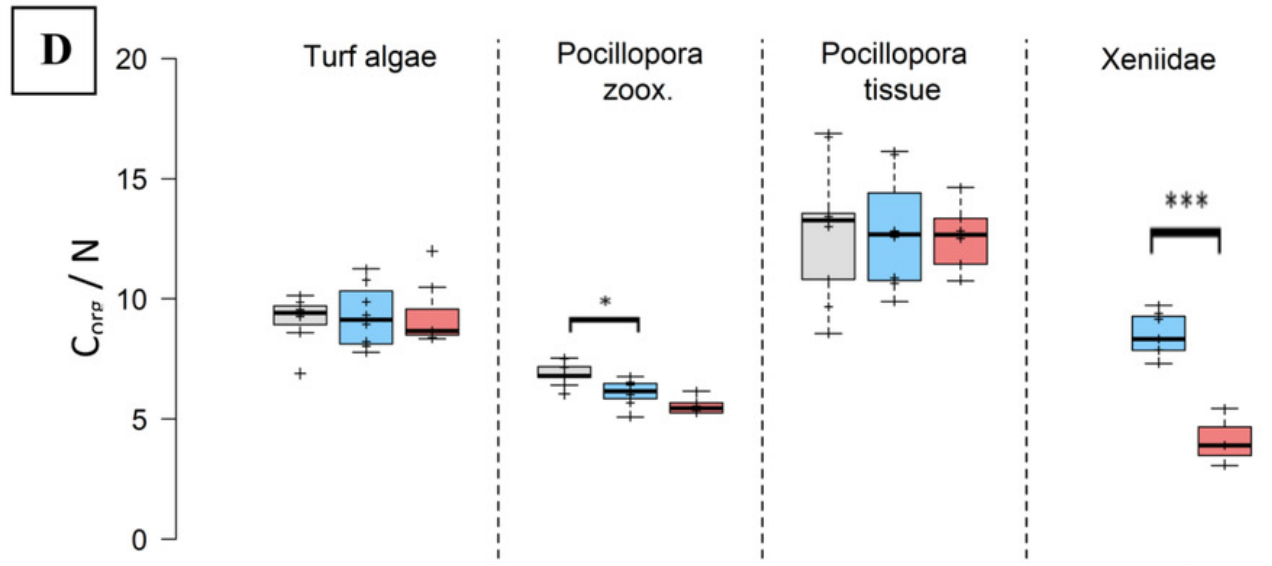

Sediments 
Figure 4

Cell density $(A)$ and mitotic index (B) of hard coral's (Pocillopora cf. verrucosa) zooxanthellae before (grey), without (blue) and with eight weeks of $\mathrm{N}$ eutrophication (red).

Error bars represent the standard error of the mean, letters $X$ and $Y$ indicate significant differences.
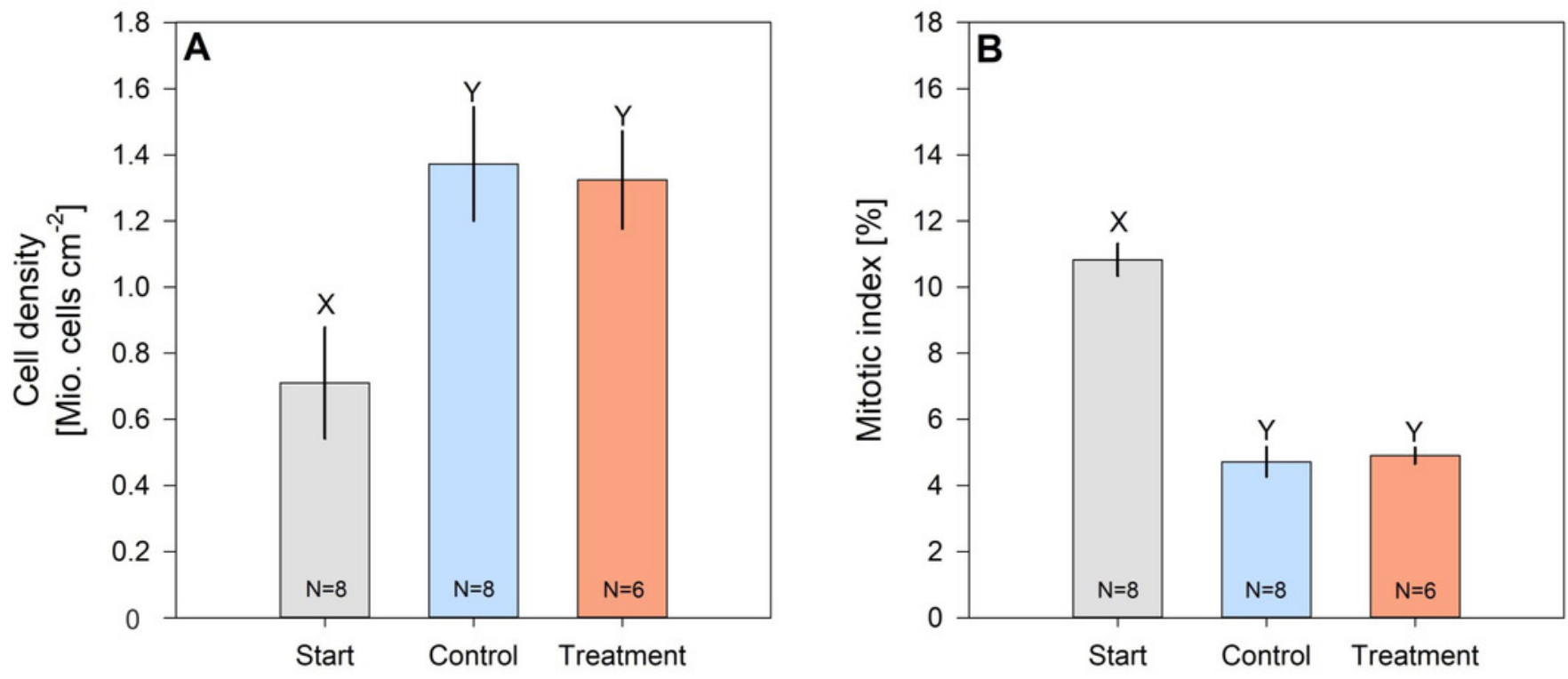